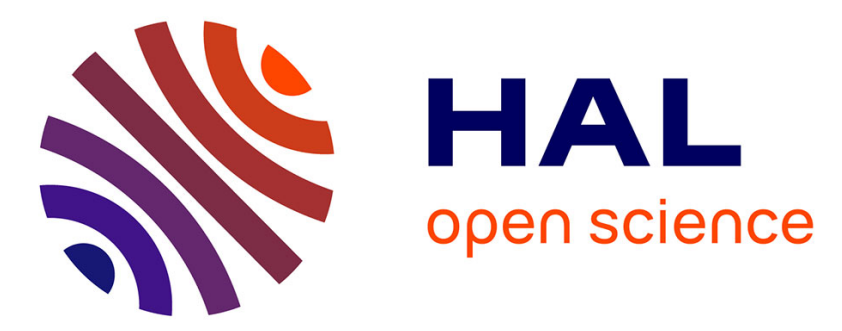

\title{
Coordination and Organometallic Chemistry of Relevance to the Rhodium-Based Catalyst for Ethylene Hydroamination
}

\author{
Aurélien Béthegnies, Vladislava A. Kirkina, Oleg A Filippov, Jean-Claude \\ Daran, Natalia V Belkova, Elena V Shubina, Rinaldo Poli
}

\section{To cite this version:}

Aurélien Béthegnies, Vladislava A. Kirkina, Oleg A Filippov, Jean-Claude Daran, Natalia V Belkova, et al.. Coordination and Organometallic Chemistry of Relevance to the Rhodium-Based Catalyst for Ethylene Hydroamination. Inorganic Chemistry, 2011, 50 (24), pp.12539-12552. 10.1021/ic201508m . hal-03157837

\section{HAL Id: hal-03157837 \\ https://hal.science/hal-03157837}

Submitted on 3 Mar 2021

HAL is a multi-disciplinary open access archive for the deposit and dissemination of scientific research documents, whether they are published or not. The documents may come from teaching and research institutions in France or abroad, or from public or private research centers.
L'archive ouverte pluridisciplinaire HAL, est destinée au dépôt et à la diffusion de documents scientifiques de niveau recherche, publiés ou non, émanant des établissements d'enseignement et de recherche français ou étrangers, des laboratoires publics ou privés. 


\title{
Coordination and organometallic chemistry of relevance
}

\section{to the rhodium-based catalyst for ethylene}

\author{
hydroamination
}

Aurélien Béthegnies, ${ }^{a}$ Vladislava A. Kirkina, ${ }^{b}$ Oleg A. Filippov, ${ }^{b}$ Jean-Claude Daran, ${ }^{a}$ Natalia V. Belkova, ${ }^{b}$ Elena Shubina ${ }^{b}$ and Rinaldo Poli ${ }^{*}, a, c$

${ }^{\mathrm{a} C N R S}$; LCC (Laboratoire de Chimie de Coordination); Université de Toulouse; UPS, INP; F-31077

Toulouse, France ; 205, route de Narbonne, F-31077 Toulouse, France; Fax: (+) 33-561553003

${ }^{b}$ A. N. Nesmeyanov Institute of Organoelement Compounds, Russian Academy of Sciences, Vavilov Street 28, 119991 Moscow, Russia.

AUTHOR EMAIL ADDRESS rinaldo.poli@lcc-toulouse.fr

RECEIVED DATE (to be automatically inserted after your manuscript is accepted if required according to the journal that you are submitting your paper to)

TITLE RUNNING HEAD. Rhodium hydroamination catalysis

CORRESPONDING AUTHOR FOOTNOTE. Fax: (+) 33-561553003. 
ABSTRACT. The $\mathrm{RhCl}_{3} \cdot 3 \mathrm{H}_{2} \mathrm{O} / \mathrm{PPh}_{3} / n \mathrm{Bu} 4 \mathrm{PI}$ catalytic system for the hydroamination of ethylene by aniline is shown to be thermally stable by a recycle experiment and by a kinetic profile study. The hypothesis of the reduction under catalytic conditions to an iodido $\mathrm{Rh}^{\mathrm{I}}$ species is supported by the observation of a high catalytic activity for complex $\left[\mathrm{RhI}\left(\mathrm{PPh}_{3}\right)_{2}\right]_{2}$. New solution equilibrium studies on $\left[\mathrm{RhX}\left(\mathrm{PPh}_{3}\right)_{2}\right]_{2}(\mathrm{X}=\mathrm{Cl}, \mathrm{I})$ in the presence of ligands of relevance to the catalytic reaction $\left(\mathrm{PPh}_{3}, \mathrm{C}_{2} \mathrm{H}_{4}\right.$, $\mathrm{PhNH}_{2}, \mathrm{X}^{-}$, and the model $\mathrm{Et}_{2} \mathrm{NH}$ amine) are reported. Complex $\left[\mathrm{RhCl}\left(\mathrm{PPh}_{3}\right)_{2}\right]_{2}$ shows broadening of the ${ }^{31} \mathrm{P}$ NMR signal upon addition of $\mathrm{PhNH}_{2}$, indicating rapid equilibrium with a less thermodynamically stable adduct. The reaction with $\mathrm{Et}_{2} \mathrm{NH}$ gives extensive conversion into cis$\mathrm{RhCl}\left(\mathrm{PPh}_{3}\right)_{2}\left(\mathrm{NHEt}_{2}\right)$, which is however in equilibrium with the starting material and free $\mathrm{Et}_{2} \mathrm{NH}$. Excess $\mathrm{NHEt}_{2}$ yields a H-bonded adduct cis- $\mathrm{RhCl}\left(\mathrm{PPh}_{3}\right)_{2}\left(\mathrm{Et}_{2} \mathrm{NH}\right) \cdots \mathrm{NHEt}_{2}$, in equilibrium with the precursors, as shown by IR spectroscopy. The iodide analogue $\left[\mathrm{RhI}\left(\mathrm{PPh}_{3}\right)_{2}\right]_{2}$ shows less pronounced reactions (no change with $\mathrm{PhNH}_{2}$, less extensive addition of $\mathrm{Et}_{2} \mathrm{NH}$ with formation of $c i s-\mathrm{RhI}_{(}\left(\mathrm{PPh}_{3}\right)_{2}\left(\mathrm{NHEt}_{2}\right)$, less extensive reaction of the latter with additional $\mathrm{Et}_{2} \mathrm{NH}$ to yield $\left.c i s-\mathrm{RhI}\left(\mathrm{PPh}_{3}\right)_{2}\left(\mathrm{Et}_{2} \mathrm{NH}\right) \cdots \mathrm{NHEt}_{2}\right)$. The two $\left[\mathrm{RhX}\left(\mathrm{PPh}_{3}\right)_{2}\right]_{2}$ compounds do not show any evidence for addition of the corresponding $\mathrm{X}^{-}$to yield a putative $\left[\mathrm{RhX}_{2}\left(\mathrm{PPh}_{3}\right)_{2}\right]^{-}$adduct. The product of $\mathrm{C}_{2} \mathrm{H}_{4}$ addition to $\left[\mathrm{RhI}\left(\mathrm{PPh}_{3}\right)_{2}\right]_{2}$, trans- $\mathrm{RhI}\left(\mathrm{PPh}_{3}\right)_{2}\left(\mathrm{C}_{2} \mathrm{H}_{4}\right)$, has been characterized in solution. Treatment of the $\mathrm{RhCl}_{3} \cdot 3 \mathrm{H}_{2} \mathrm{O} / \mathrm{PPh}_{3} / n \mathrm{Bu}_{4} \mathrm{PI} / \mathrm{PhNH}_{2}$ mixture under catalytic conditions yields mostly $\left[\mathrm{RhCl}\left(\mathrm{PPh}_{3}\right)_{2}\right]_{2}$ and no significant halide exchange, demonstrating that the promoting effect of iodide must take place at the level of high energy catalytic intermediates. The equilibria have also been investigated at the computational level by DFT with treatment at the full QM level including solvation effects. The calculations confirm that the bridge splitting reaction is slightly less favourable for the iodido derivative. Overall, the study confirms the active role of rhodium(I) species in ethylene hydroamination catalyzed by $\mathrm{RhCl}_{3} \cdot 3 \mathrm{H}_{2} \mathrm{O} / \mathrm{PPh}_{3} / n \mathrm{Bu}_{4} \mathrm{PI}$ and suggest that the catalyst resting state is $\left[\mathrm{RhCl}\left(\mathrm{PPh}_{3}\right)_{2}\right]_{2}$ or its $\mathrm{C}_{2} \mathrm{H}_{4}$ adduct, $\mathrm{RhCl}\left(\mathrm{PPh}_{3}\right)_{2}\left(\mathrm{C}_{2} \mathrm{H}_{4}\right)$, under high ethylene pressure.

KEYWORDS. Rhodium; triphenylphosphine; coordination chemistry; intermolecular hydroamination; 
DFT calculations.

BRIEFS. Complex $\left[\mathrm{RhI}\left(\mathrm{PPh}_{3}\right)_{2}\right]_{2}$ is an active catalyst for ethylene hydroamination by aniline; its coordination chemistry in the presence of catalytic relevant ligands is reported.

\section{Introduction}

An efficient halide-promoted platinum catalyst has recently been developed in our group for the hydroamination of ethylene and $\alpha$-olefins by aniline derivatives. ${ }^{1-6}$ This reaction yields $N$-ethylaniline (1) as major product, accompanied by traces of the double hydroamination product $N, N$-diethylaniline (2) and by minor amounts of quinaldine (3), see Scheme 1. Synthetic, spectroscopic and solution equilibrium studies ${ }^{5,7,8}$ assisted by DFT calculations ${ }^{9,10}$ have elucidated important mechanistic details of the hydroamination cycle and have rationalized experimental observations such as the halide promotion effects, the higher activity for the addition of less basic aniline derivatives, the strong preference for Markovnikov addition to higher olefins, and also hinted to the importance of the substrate and/or halide basicity in the deprotonation of a zwitterionic intermediate as a key step leading to catalyst deactivation. $^{11}$

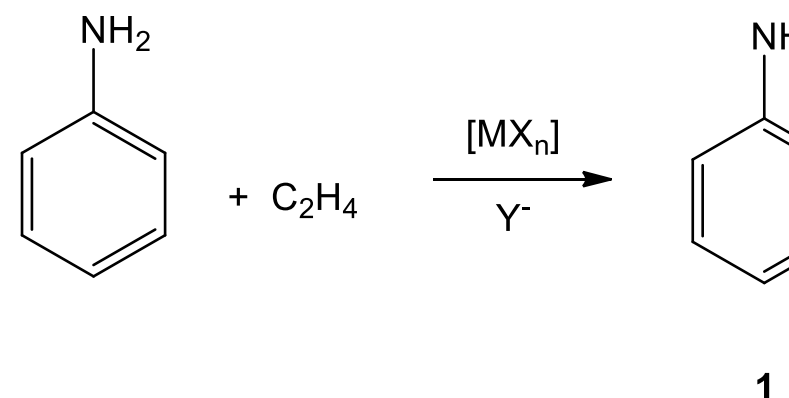

1

2

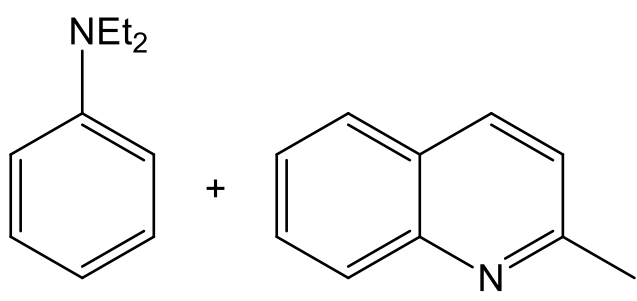

3

Scheme 1. Products observed in the halide-promoted catalyzed hydroamination of ethylene by aniline $\left(\mathrm{MX}_{\mathrm{n}} / \mathrm{Y}^{-}=\mathrm{PtBr}_{2} / \mathrm{Br}^{-}\right.$or $\left.\mathrm{RhCl}_{3} \cdot 3 \mathrm{H}_{2} \mathrm{O} / \mathrm{I}^{-}\right)$.

A few years ago, it has also been reported within our group that halides equally promote the aniline 
addition to ethylene when catalyzed by $\mathrm{RhCl}_{3} \cdot 3 \mathrm{H}_{2} \mathrm{O} / \mathrm{PPh}_{3}{ }^{12}$ Compound $\mathrm{RhCl}_{3} \cdot 3 \mathrm{H}_{2} \mathrm{O}$ had previously been shown to efficiently catalyze the addition of basic secondary amines ( $\mathrm{Et}_{2} \mathrm{NH}$, piperidine) to ethylene, albeit under rather forcing conditions, but the efficiently was greatly reduced for less basic amines or for higher olefins. ${ }^{13,}{ }^{14}$ Subsequent work had shown that addition of $\mathrm{PPh}_{3}$ to this system allows ethylene hydroamination by aniline, but only with much lower efficiencies. ${ }^{15-17}$ A few welldefined complexes were also briefly investigated, giving low productivities and/or fast decomposition. ${ }^{18-20}$ The work from our group has revealed that the same catalytic system, like $\mathrm{PtBr}_{2}$, becomes much more active for the addition of aniline to ethylene when promoted by halide ions and the strongest promoting effect for this system turned out to be associated to iodide; under these conditions, greater amounts of double hydroamination product 2 were obtained relative to the $\mathrm{PtBr}_{2} / \mathrm{Br}^{-}$system, whereas the quinaldine by-product $\mathbf{3}$ was essentially absent. ${ }^{12}$

The promoting effect of halide ions in homogeneous catalysis is not unprecedented. For instance, the catalytic activity of a series of $\operatorname{Ir}(\mathrm{I})$ diphosphine complexes in intermolecular hydroamination (of norbornene by aniline), was shown to be greatly improved in the presence of fluoride ions, ${ }^{21}$ whereas iodide is a recognized promoter for a variety of other catalyzed processes, ${ }^{22}$ especially the Rh and Ircatalyzed methanol carbonylation. The origin of its promoting effect, however, is not always completely understood, being possibly associated to a number of possible causes such as its good nucleophilicity, its redox activity, or simply its better binding to low-valent metal centers decreasing the tendency of the metal complex to precipitate and two or more effects may occur in different steps of the same catalytic cycle. ${ }^{22}$ For the $\mathrm{PtBr}_{2}$ hydroamination, as already stated, halides are also promoters and in that case bromide shows the strongest effect, ${ }^{1}$ though only marginally better than iodide and the reasons of this difference are not yet understood. ${ }^{11}$

Given the rather reducing conditions imposed by the ethylene and aniline reagents (catalyst degradation to metallic rhodium was reported under certain conditions) it is reasonably assumed that $\mathrm{RhCl}_{3} \cdot 3 \mathrm{H}_{2} \mathrm{O}$ is transformed to a $\mathrm{Rh}^{\mathrm{I}}$ complex, probably containing $\mathrm{PPh}_{3}$ and iodide ligands, before 
beginning the catalytic cycle. However, the coordination chemistry of iodide complexes of $\mathrm{Rh}^{\mathrm{I}}$ has been little explored, particularly with the set of ligands of relevance to this catalytic reaction. Complex $\mathrm{RhI}\left(\mathrm{PPh}_{3}\right)_{3}$ (the iodide equivalent of Wilkinson's catalyst) has been described by Wilkinson himself, ${ }^{23}$ and the dinuclear complex $\left[\mathrm{RhI}\left(\mathrm{PPh}_{3}\right)_{2}\right]_{2}$ is also known. ${ }^{23-25}$ With the notable exception of Vaska-type, $\mathrm{CO}$ containing complexes, ${ }^{26,27}$ adducts with other ligands are scarce and this coordination chemistry merits renewed attention in view of this specific catalytic transformation.

Following the same strategy recently adopted for the study of the platinum-based catalyst, ${ }^{5}$ we have decided to investigate well-defined rhodium complexes in terms of their solution equilibria in the presence of all available ligands under catalytic conditions (triphenylphosphine, ethylene, aniline, halide). DFT calculations have also been carried out to validate the experimental findings. Finally, additional catalytic tests have been run in the presence of well-defined $\mathrm{Rh}^{\mathrm{I}}$ iodide complexes, validating the concept that the active catalyst is indeed a $\mathrm{Rh}^{\mathrm{I}}$ species.

\section{Experimental Section}

General. Unless otherwise stated, all manipulations were carried out under an argon atmosphere. Solvents were dehydrated by standard procedures and distilled under argon prior to use. Compounds $\mathrm{RhCl}_{3} \cdot 3 \mathrm{H}_{2} \mathrm{O}$ (Johnson Matthey 41.92\%), $\mathrm{PPh}_{3}$ (Aldrich 99\%), $\mathrm{nBu}_{4} \mathrm{NCl}($ Fluka $>97 \%$ ) and $\mathrm{nBu} 4 \mathrm{PBr}$ (Acros Organics) were used as received. Tetra(n-butyl)phosphonium iodide was prepared from $\mathrm{nBu}_{3} \mathrm{P}$ and $\mathrm{nBuI}$ according to the literature ${ }^{4}$ and stored protected from light and under argon in a freezer. $\mathrm{Et}_{2} \mathrm{NH}$ (Fluka), $\mathrm{PhNH}_{2}$ (Acros Organics; 99\% for analysis ACS) and mesitylene ( $>97 \%$, Fluka) were distilled and kept under argon in the dark. Ethylene (N25, purity $\geq 99.5 \%$ ) was purchased from Air Liquide. Complexes $\mathrm{RhCl}\left(\mathrm{PPh}_{3}\right)_{3},{ }^{23}\left[\mathrm{RhCl}\left(\mathrm{PPh}_{3}\right)_{2}\right]_{2},{ }^{23} \mathrm{RhI}\left(\mathrm{PPh}_{3}\right)_{3}{ }^{24}$ and $\left[\mathrm{RhI}\left(\mathrm{PPh}_{3}\right)_{2}\right]_{2}{ }^{24}$ were synthesized according to literature procedures. Single crystals of $\mathrm{RhI}\left(\mathrm{PPh}_{3}\right)_{3}$ were grown by diffusion of pentane into a dichloromethane solution. 
Instrumentation. The GC analyses were performed on a Hewlett-Packard HP4890 (FID) chromatograph (HP 3395 integrator) equipped with a 30mx0.320mmx0.25 $\mu \mathrm{m}$ HP1 capillary column (DB-5MS). The NMR investigations were carried out on Bruker DPX 300 and AV300 spectrometers at $298 \mathrm{~K}$ operating at $300.13 \mathrm{MHz}\left({ }^{1} \mathrm{H}\right)$ and $121.495 \mathrm{MHz}\left({ }^{31} \mathrm{P}\right)$. IR measurements were carried out on Nicolet 6700 spectrometer using $\mathrm{CaF}_{2}$ cell.

Reaction of $\mathbf{R h C l}\left(\mathbf{P P h}_{3}\right)_{3}$ with $\mathbf{P h N H}$. In a $5 \mathrm{~mm} \mathrm{NMR}$ tube was placed $\left[\mathrm{RhCl}\left(\mathrm{PPh}_{3}\right)_{3}\right](10.7 \mathrm{mg}$, $0.012 \mathrm{mmol}$ ) and dissolved in ca. $0.7 \mathrm{~mL}$ of $\mathrm{CD}_{2} \mathrm{Cl}_{2}$. The solution composition was checked by ${ }^{31} \mathrm{P}\left\{{ }^{1} \mathrm{H}\right\}$ NMR, revealing the presence of a minor amount of $\left[\mathrm{RhCl}\left(\mathrm{PPh}_{3}\right)_{2}\right]_{2}$ and free $\mathrm{PPh}_{3}$, with which the starting compound is in equilibrium. $\mathrm{PhNH}_{2}$ was added by microsyringe and the progress of the reaction monitored by ${ }^{31} \mathrm{P}\left\{{ }^{1} \mathrm{H}\right\} 1$ NMR. No change in the spectrum was observed upon introduction of up to 11 eq. of $\mathrm{PhNH}_{2}$, except for the broadening of the doublet resonance of the dinuclear complex $\left[\mathrm{RhCl}\left(\mathrm{PPh}_{3}\right)_{2}\right]_{2}$.

Reaction of $\left[\mathrm{RhCl}\left(\mathrm{PPh}_{3}\right)_{2}\right]_{2}$ with amines. (a) $\mathbf{P h N H}$. In a $5 \mathrm{~mm}$ NMR tube was introduced $\left[\mathrm{RhCl}\left(\mathrm{PPh}_{3}\right)_{2}\right]_{2}(10.06 \mathrm{mg}, 0.016 \mathrm{mmol})$ and dissolved in ca. $0.7 \mathrm{~mL}$ of $\mathrm{CD}_{2} \mathrm{Cl}_{2}$. After checking the quality of the compound, $\mathrm{PhNH}_{2}$ was added by microsyringe and the progress of the reaction monitored by ${ }^{31} \mathrm{P}\left\{{ }^{1} \mathrm{H}\right\} \mathrm{NMR}$, indicating only a weak affinity of this amine for bonding (see text).

(b) $\mathbf{E t}_{2}$ NH. In a $5 \mathrm{~mm} \mathrm{NMR} \mathrm{tube} \mathrm{was} \mathrm{introduced}\left[\mathrm{RhCl}\left(\mathrm{PPh}_{3}\right)_{2}\right]_{2}\left(5.4 \mathrm{mg}, 8.15 \cdot 10^{-3} \mathrm{mmol}\right)$ and dissolved in ca. $0.7 \mathrm{~mL}$ of $\mathrm{CD}_{2} \mathrm{Cl}_{2}$. After checking the quality of the compound, $\mathrm{Et}_{2} \mathrm{NH}$ was added by microsyringe and the progress of the reaction monitored by ${ }^{31} \mathrm{P}\left\{{ }^{1} \mathrm{H}\right\}$ NMR, giving evidence for quantitative formation of $c i s-\mathrm{RhCl}_{(}\left(\mathrm{PPh}_{3}\right)_{2}\left(\mathrm{Et}_{2} \mathrm{NH}\right)$ in the presence of excess $\mathrm{Et}_{2} \mathrm{NH}$ (see text). A solution prepared separately in a Schlenk tube with the same concentration and excess $\mathrm{Et}_{2} \mathrm{NH}$ was set out for crystallization by diffusion of a pentane layer, affording single crystals of $\left[\mathrm{RhCl}\left(\mathrm{PPh}_{3}\right)_{2}\right]_{2}$.

Reaction of $\left[\mathbf{R h I}\left(\mathbf{P P h}_{3}\right)_{2}\right]_{2}$ with amines. The reaction of compound $\left[\mathrm{RhI}\left(\mathrm{PPh}_{3}\right)_{2}\right]_{2}$ with both $\mathrm{PhNH}_{2}$ and $\mathrm{Et}_{2} \mathrm{NH}$ was carried out in $\mathrm{CD}_{2} \mathrm{Cl}_{2}$ inside an NMR tube, following the same experimental protocol descrived above for the related $\left[\mathrm{RhCl}\left(\mathrm{PPh}_{3}\right)_{2}\right]_{2}$ system. 
Reaction of $\left[\mathbf{R h I}\left(\mathbf{P P h}_{3}\right)_{2}\right]_{2}$ with $\mathbf{C}_{2} \mathbf{H}_{4}$. Compound $\left[\mathrm{RhI}\left(\mathrm{PPh}_{3}\right)_{2}\right]_{2}(10 \mathrm{mg}, 0.013 \mathrm{mmol})$ was suspended in $2 \mathrm{~mL}$ of $\mathrm{CD}_{2} \mathrm{Cl}_{2}$ in a Schlenk tube. The argon atmosphere was then replaced with ethylene and the suspension was stirred at room temperature. After a few minutes, the precipitate dissolved to yield a clear, yellow solution. ${ }^{1} \mathrm{H}$ NMR $\left(\mathrm{CD}_{2} \mathrm{Cl}_{2}\right): \delta 6.0-6.25(30 \mathrm{H}, \mathrm{Ph}), 4.43$ (broad, $\left.4 \mathrm{H}, \mathrm{C}_{2} \mathrm{H}_{4}\right) .{ }^{31} \mathrm{P}$ $\operatorname{NMR}\left(\mathrm{CD}_{2} \mathrm{Cl}_{2}\right): \delta 35.8\left(\mathrm{~d},{ }^{1} \mathrm{~J}_{\mathrm{P}-\mathrm{Rh}}=124 \mathrm{~Hz}\right)$. An analogous experiment was carried out in toluene- $d_{6}$, resulting in the same behavior except that the solubilization of the precursor required stirring for $24 \mathrm{~h}$.

Ethylene hydroamination catalysis. (a) Standard catalytic runs. The catalytic experiments were conducted in a $100 \mathrm{~mL}$ stainless steel thermoregulated (electric oven) autoclave with a stirring bar. In a

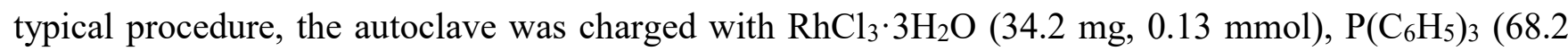
$\mathrm{mg}, 0.26 \mathrm{mmol})$ and $n \mathrm{Bu} 4 \mathrm{PI}(3.26 \mathrm{~g}, 8.45 \mathrm{mmol})$, closed and submitted to several argon-vacuum cycles. Distilled and degassed aniline $(4.1 \mathrm{~mL}, 45 \mathrm{mmol})$ was then syringed into the autoclave. The ethylene pipe was connected to the autoclave, purged, and the pressure was adjusted to 25 bars at RT. The temperature was then raised to $150^{\circ} \mathrm{C}$. After $96 \mathrm{~h}$, the autoclave was allowed to cool down to room temperature and slowly vented. The reaction mixture was then poured into $120 \mathrm{~mL}$ of diethylether and the resulting suspension was stirred for $2 \mathrm{~h}$ and then filtered. The external standard N,N-di- $n$ butylaniline, (ca. $0.15 \mathrm{~g}$ ) was added to the collected ethereal phases and the solution analysed by GC.

(b) Concentration monitoring experiments. An autoclave equipped with a siphon for sample withdrawal was charged with $\mathrm{RhCl}_{3} \cdot 3 \mathrm{H}_{2} \mathrm{O}, \mathrm{P}\left(\mathrm{C}_{6} \mathrm{H}_{5}\right)_{3}$ and $n \mathrm{Bu} 4 \mathrm{PI}$ in similar amounts to the previous experiment, closed and submitted to several argon-vacuum cycles. Distilled and degassed aniline (4.1 $\mathrm{mL}, 45 \mathrm{mmol}$ ) and mesitylene (distilled and degassed, $16 \mathrm{~mL}$ ) were then syringed into the autoclave. The dilution with mesitylene was necessary in order to allow the withdrawal of a sufficient number of samples. Ethylene was finally added and the reaction carried out as described above. Samples of ca. 0.5 $\mathrm{mL}$ were withdrawn are different times through the siphon and poured into $3.5 \mathrm{~mL}$ of diethylether, followed by stirring. The external standard N,N-di- $n$-butylaniline, (ca. $0.010 \mathrm{~g}$ ) was added to the collected ethereal phases and filtered before being analysed by GC. 
(c) Consecutive catalytic runs. A first catalytic run was carried out as described above in (a), until after venting the leftover ethylene from the autoclave. Degassed and distilled diethylether $(50 \mathrm{~mL})$ was syringed into the autoclave under an argon flow and the mixture was stirred for $2 \mathrm{~h}$. After one hour of settling, the supernatant liquid was transferred from the autoclave to a collector flask through the siphon. The operation was repeated several times until the transferred liquid was colourless. The external standard $N, N$-di- $n$-butylaniline (ca. $0.010 \mathrm{~g}$ ) was added to the collected ethereal phases and filtered before being analysed by GC. Subsequently, the autoclave was submitted to vacuum for $2 \mathrm{~h}$ and refilled with argon. A new charge of distilled and degassed aniline $(4.1 \mathrm{~mL}, 45 \mathrm{mmol})$ was then syringed into the autoclave. Ethylene was then introduced and the second catalytic run as carried out as described in (a), including the work up procedure.

Reaction of $\mathrm{RhCl}_{3} \cdot \mathrm{HH}_{2} \mathrm{O}$ with $\mathrm{PPh}_{3}, \mathrm{Bu}_{4} \mathrm{NI}$ and aniline. In a Schlenk tube were introduced $\mathrm{RhCl}_{3} \cdot 3 \mathrm{H}_{2} \mathrm{O}$ (34 mg, $\left.0.13 \mathrm{mmol}\right), \mathrm{PPh}_{3}(68.2 \mathrm{mg}, 0.26 \mathrm{mmol}), \mathrm{Bu} 4 \mathrm{NI}(820 \mathrm{mg}, 2.1 \mathrm{mmol})$. After purging with Ar, aniline $(1 \mathrm{~mL}, 11.4 \mathrm{mmol})$ was added and the resulting mixture was stirred at room temperature for $15 \mathrm{~min}$, then at $150^{\circ} \mathrm{C}$ for $16 \mathrm{~h}$. The color of the mixture darkened to red-brown during the first $10 \mathrm{~min}$ of heating, then it did not further change. After cooling, $0.4 \mathrm{~mL}$ of the solution were transferred into a $5 \mathrm{~mm}$ NMR tube together with ca. $0.1 \mathrm{~mL}$ of $\mathrm{CD}_{2} \mathrm{Cl}_{2}$ for a ${ }^{31} \mathrm{P} \mathrm{NMR}$ analysis (see text).

X-ray crystallography. A single crystal of each compound was mounted under inert perfluoropolyether on the tip of a cryoloop and cooled in the cryostream of either an Agilent Technologies GEMINI EOS CCD diffractometer for $\left[\mathrm{RhCl}\left(\mathrm{PPh}_{3}\right)_{2}\right]_{2}$ or an Oxford-Diffraction XCALIBUR SAPPHIRE-I CCD diffractometer for $\mathrm{RhI}\left(\mathrm{PPh}_{3}\right)_{3}$. Data were collected using the monochromatic MoK $\alpha$ radiation $(\lambda=0.71073)$.

The structures were solved by direct methods (SIR97) ${ }^{28}$ and refined by least-squares procedures on $F^{2}$ using SHELXL-97. ${ }^{29}$ In compound $\left[\mathrm{RhCl}\left(\mathrm{PPh}_{3}\right)_{2}\right]_{2}$, some residual electron density was difficult to model. Therefore, the SQUEEZE function of PLATON ${ }^{30}$ was used to eliminate the contribution of the 
electron density in the solvent region from the intensity data, and the solvent-free model was employed for the final refinement. There is one cavity of $238 \AA$ per unit cell. PLATON estimated that the cavity contains 35 electrons which may correspond to a solvent molecule of dichloromethane as suggested by chemical analyses. All $\mathrm{H}$ atoms attached to carbon were introduced in idealised positions and treated as riding on their parent atoms in the calculations. The drawing of the molecules was realised with the help of ORTEP3. ${ }^{31,32}$ Crystal data and refinement parameters are shown in Table 1.

Crystallographic data (excluding structure factors) have been deposited with the Cambridge Crystallographic Data Centre as supplementary publication no. CCDC $828152 \& 828153$. Copies of the data can be obtained free of charge on application to the Director, CCDC, 12 Union Road, Cambridge CB2 1EZ, UK (fax: (+44) 1223-336-033; e-mail: deposit@,ccdc.cam.ac.uk).

Table 1. Crystal data and structure refinement

$\begin{array}{llc}\text { Compound } & {\left[\mathrm{RhCl}\left(\mathrm{PPh}_{3}\right)_{2}\right]_{2}} & \mathrm{RhI}\left(\mathrm{PPh}_{3}\right)_{3} \\ \text { Empirical formula } & \mathrm{C}_{36} \mathrm{H}_{30} \mathrm{ClP}_{2} \mathrm{Rh} & \mathrm{C}_{54} \mathrm{H}_{45} \mathrm{IP}_{3} \mathrm{Rh} \\ \text { Formula weight } & 662.90 & 1016.62 \\ \text { Temperature, K } & 180(2) & 180(2) \\ \text { Wavelength, } \AA & 0.71073 & 0.71073 \\ \text { Crystal system } & \text { Triclinic } & \text { Orthorhombic } \\ \text { Space group } & \mathrm{P}-1 & \mathrm{Pna} 21 \\ \text { a, } \AA & 9.7226(2) & 19.7950(8) \\ \mathrm{b}, \AA & 12.6361(3) & 12.6130(6) \\ \mathrm{c}, \AA & 13.7002(4) & 17.7058(8) \\ \alpha,{ }^{\circ} & 85.091(2) & 90.0 \\ \beta, \circ & 83.067(2) & 90.0\end{array}$


Volume, $\AA^{3}$

Z

Density (calculated), $\mathrm{Mg} / \mathrm{m}^{3}$

Absorption coefficient, $\mathrm{mm}^{-1}$

$\mathrm{F}(000)$

Crystal size, $\mathrm{mm}^{3}$

Theta range, ${ }^{\circ}$

Reflections collected

Independent reflections $\left(\mathrm{R}_{\text {int }}\right)$

Completeness, \%

Absorption correction

Max. and min. transmission

Refinement method

Data / restraints / parameters

Goodness-of-fit on $\mathrm{F}^{2}$

$\mathrm{R} 1, \mathrm{wR} 2[\mathrm{I}>2 \sigma(\mathrm{I})]$

R1, wR2 (all data)

Absolute structure parameter

Residual density, e. $\AA^{-3}$
$1638.78(7)$

2

1.343

0.723

676

$0.24 \times 0.19 \times 0.14$

$3.60-27.48$.

35493

$7439(0.0337)$

98.8

Multi-scan

$1.0 / 0.8750$

$\mathrm{F}^{2}$

7439 / 0 / 361

1.081

$0.0283,0.0893$

$0.0361,0.0938$

$0.487 /-0.325$
4420.7(3)

4

1.180

1.211

1556

$0.48 \times 0.37 \times 0.31$

$2.99-26.37$.

24208

$8931(0.0234)$

99.8

Multi-scan

0.7053 / 0.5941

$\mathrm{F}^{2}$

$8931 / 1 / 532$

1.049

$0.0236,0.0558$

$0.0275,0.0570$

$0.008(11)$

$0.475 /-0.753$

Computational Details. Calculations were performed with the Gaussian09 package ${ }^{33}$ at the DFT/M06 level ${ }^{34}$ without any ligand simplification. Effective core potentials (ECP) and its associated SDD basis set $^{35-38}$ supplemented with f-polarization functions $(\operatorname{SDD}(\mathrm{f}))^{39}$ were applied for rhodium atom and those supplemented with diffuse and polarization set of exponents $(\mathrm{SDD}(\mathrm{pd}))^{40}$ used for iodine 
atoms. Tests were also carried out using the $\mathrm{g}-311 \mathrm{G}^{* *}$ basis set for the $\mathrm{I}$ atom, ${ }^{41}$ leading to no difference for the relative energy of cis and trans isomers. The carbon and hydrogen atoms of the phenyl rings of $\mathrm{PPh}_{3}$ ligands were described with 6-31G basis set; $\mathrm{P}$ atoms and organic ligands $\left(\mathrm{C}_{2} \mathrm{H}_{4}, \mathrm{PhNH}_{2}, \mathrm{Et}_{2} \mathrm{NH}\right)$ were described with a $6-31 \mathrm{G}(\mathrm{d}, \mathrm{p})$ set of basis functions. Scaling factors were not applied to the calculated frequencies. Non-specific solvent effects were introduced through SMD solvation model ${ }^{42}$ by single-point energy calculations on gas phase optimized geometries for dichloromethane $(\varepsilon=8.93)$. The $\mathrm{G}^{\mathrm{SMD}}$ values account for the solvation free energies, with inclusion of the solute free energy contributions $\Delta G^{\mathrm{SMD}}=\Delta E^{\mathrm{SMD}}+\Delta G^{\mathrm{gas}}-\Delta E^{\mathrm{gas}}$, where $\Delta E^{\mathrm{SMD}}$ is the electronic energy plus the solvent entropy. ${ }^{43}$

\section{Results and Discussion}

\section{(a) Hydroamination catalysis}

Before addressing the chemistry of well defined $\mathrm{Rh}^{\mathrm{I}}$ complexes in solution, we present catalytic results that give additional information on the catalyst stability and mode of action. Within a previous $\mathrm{PtBr}_{2}$-catalyzed investigation, ${ }^{6}$ it has become obvious to us that the use of a glass liner, systematically used in previously published work, was causing an artificial decrease of the measured activity and a loss of reproducibility because of the high temperature conditions and the resulting condensation of aniline vapours in the catalyst-free zone of the autoclave underneath the liner. We have therefore repeated a selected number of previously reported experiments ${ }^{12}$ without the glass liner in the autoclave. The results are shown in Table 2 . Note that the catalytic reactions run with the $\mathrm{RhCl}_{3} \cdot 3 \mathrm{H}_{2} \mathrm{O} / \mathrm{I}^{-}$catalyst require a much longer time (4 days) than those carried out with the $\mathrm{PtBr}_{2} / \mathrm{Br}^{-}$catalytic systems $(10 \mathrm{~h})$ in order to achieve reasonable conversions, because of the lower TOF of the former catalyst.

Table 2. Hydroamination of ethylene by aniline catalyzed by $\mathrm{RhCl}_{3} \cdot 3 \mathrm{H}_{2} \mathrm{O}$. 


\begin{tabular}{cccccccc}
\hline Run & $\mathrm{I}^{-} / \mathrm{Rh}$ & $\mathrm{I}_{2} / \mathrm{Rh}$ & Conv./\% & TON 1 & TON 2 & TON 3 & CE $^{\mathrm{b}}$ \\
\hline 1 & 10 & - & $13(14)$ & $42(47)$ & $4(3)$ & $-(-)$ & $49(53)$ \\
2 & 65 & - & $83(65)$ & $50(130)$ & $239(93)$ & $1(4)$ & $531(324)$ \\
3 & 150 & - & $69(65)$ & $138(102)$ & $100(120)$ & $2(5)$ & $341(352)$ \\
4 & 65 & 2 & $57(73)$ & $150(28)$ & $51(225)$ & $-(3)$ & $251(484)$ \\
5 & $\mathrm{c}$ & - & 2 & 6 & 0 & 0 & 5 \\
$6(1)$ & & & 73 & 28 & 229 & 1 & 488 \\
$6(2)$ & 65 & - & 86 & 37 & 266 & 0 & 570
\end{tabular}

${ }^{a}$ Values in parentheses are those reported in the previous contribution. ${ }^{12}$ Conditions: $\mathrm{RhCl}_{3} \cdot 3 \mathrm{H}_{2} \mathrm{O}(34.2$ $\mathrm{mg}, 0.13 \mathrm{mmol}$ ), $\mathrm{PPh}_{3}$ (68.2 mg, $0.26 \mathrm{mmol}, 2$ equiv), $n$-Bu4 $\mathrm{PI}, \mathrm{PhNH}_{2}$ (4.1 mL, $45.5 \mathrm{mmol}, 350$ equiv), $\mathrm{C}_{2} \mathrm{H}_{4}\left(25\right.$ bars; ca. 770 equiv), $150^{\circ} \mathrm{C}, 96 \mathrm{~h} .{ }^{\mathrm{b}} \mathrm{CE}$ (catalytic efficiency) $=\mathrm{TON} 1+2(\mathrm{TON} 2)+2(\mathrm{TON}$ 3). ${ }^{\mathrm{c}}$ Same amounts of all reagents as in entry 2 , in the absence of $\mathrm{RhCl}_{3} \cdot 3 \mathrm{H}_{2} \mathrm{O}$.

The catalytic efficiency (CE) is calculated on the basis of the number of cycles needed by the catalyst to yield each product (two cycles for $\mathbf{2}$ and $\mathbf{3}$ ). As can be seen, while certain experiments gave essentially the same results (e.g. runs 1 and 3), others gave significantly improved conversions and catalytic efficiencies (run 2). All new results obtained without glass liner were repeated and found to be reproducible within $6 \%$. The new results give the highest activity for a 65 -fold excess of the iodide salt. Repetition of the experiment carried out in the presence of the $I_{2}$ additive, however, showed lower efficiency in the absence of the glass liner. The higher activity previously reported with glass liner has indeed been reproduced by us (an even greater catalytic efficiency of 542 has been obtained, which is essentially identical to the activity found without $I_{2}$ and without glass liner, entry 2). Hence, while $I_{2}$ was believed to have a promoting effect on the catalysis when this was carried out inside a glass liner, the opposite effect is found when the solution is in contact with the stainless steel autoclave walls. The reason for this change is currently not clear, but may be related to the negative interference, only after reaction with $\mathrm{I}_{2}$, of unknown species chemisorbed on the autoclave walls. At any rate, the fact that the activity in the presence of $\mathrm{I}_{2}$ when using a glass liner ${ }^{12}$ is not better than that in the absence of $\mathrm{I}_{2}$ without glass liner (run 2) shows that $I_{2}$ has no promoting effect on this catalysis. A control experiment run 
under the same conditions but without $\mathrm{RhCl}_{3} \cdot 3 \mathrm{H}_{2} \mathrm{O}$ gave insignificant amounts of hydroamination (run $5)$.

One important question concerns catalyst deactivation, since this was shown to occur and to limit the TON for the related $\mathrm{PtBr}_{2} / \mathrm{Br}^{-}$-catalyzed reaction: the catalyst turned into a black deposit (probably metallic Pt) with no residual catalytic activity. ${ }^{6}$ In order to address this question for the Rh-based catalyst, we ran two subsequent experiments in the same autoclave under the same conditions as run 2 , with the same catalyst charge, the second run being carried out after removing the product mixture of the first run, washing the solid catalyst several times (all operations were carried out inside the sealed autoclave under argon), and introducing a new charge of aniline and ethylene reagents (see details in the experimental section). The results are shown in Table 2 (run 6). As clearly seen, a similar catalytic efficiency is obtained for the first and the second run, and both are in good agreement with those of the single run of entry 2. As a matter of fact, the discrepancy between the activities in the first and second run (the first being slightly smaller and the second slightly higher than for entry 2) is a bit greater than the usual reproducibility level mentioned above. We tentatively attribute this discrepancy to an incomplete recovery, in spite of several washings, of the products from the first run (there is a significant dead volume between the bottom of the autoclave and the siphon nozzle), which have therefore remained in the autoclave and added to those produced in the second run, artificially lowering the results of the first run and increasing those of the second one. At any rate, the experiment proves that the catalyst retains most of its activity after 4 days of operations at $150^{\circ} \mathrm{C}$. Hence, this catalyst is more robust than the $\mathrm{PtBr}_{2} / \mathrm{Br}^{-}$system. ${ }^{1,6}$

Additional information on the progress of the catalytic reaction was obtained by monitoring the substrate and product concentrations with time. The conditions used are those of entry 2 of Table 2 , except that a diluent (mesitylene) was added in order to allow a sufficient number of sample withdrawals, again because of the large dead volume below the siphon nozzle. The results are shown in Figure 1(a). The amount of aniline could not be determined accurately in this case because of peak 
overlap with the mesitylene diluent, but the peak separation was sufficient to demonstrate the essentially complete consumption of aniline at the end of the catalytic run. The conversion proceeded smoothly to first yield $\mathbf{1}$ and subsequently $\mathbf{2}$, consistent with the notion that $\mathbf{1}$ is an intermediate in the generation of 2. The absence of a notable induction time indicates a rapid conversion of the precatalyst to the active species. Quinaldine (3) was formed in small amounts throughout the reaction and it is not possible to conclude whether this reaction leading to this by-product proceeds through $\mathbf{1}$ or not. The evolution of the sum of the three products $(\mathbf{1}+\mathbf{2}+\mathbf{3})$ seems linear, suggesting zero-order in aniline. After $70 \mathrm{~h}$ essentially no aniline is left in the mixture and the sum of all products no longer increases, while the transformation of $\mathbf{1}$ into $\mathbf{2}$ continues to take place. The essentially complete aniline consumption is in line with the absence of catalyst deactivation, as already indicated above. The final mass balance is good, the three products accounting for $>85 \%$ of the aniline amount charged in the autoclave, according to the GC calibration. A second reaction monitoring was also carried out with a double ethylene pressure (50 bar), giving very similar results, see Figure 1(b).
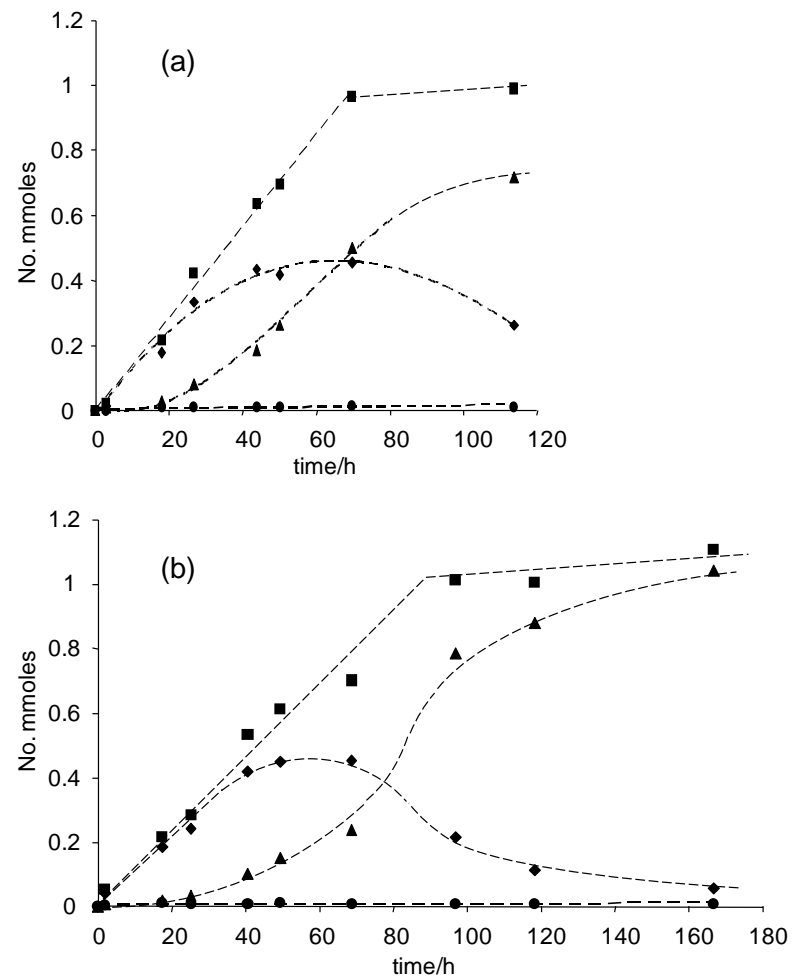

Figure 1. Kinetic profile of the $\mathrm{RhCl}_{3} \cdot 3 \mathrm{H}_{2} \mathrm{O}$-catalyzed reaction between $\mathrm{PhNH}_{2}$ and $\mathrm{C}_{2} \mathrm{H}_{4}: \mathbf{1}(\diamond), 2(\boldsymbol{\Delta})$, 
$3(-), 1+2+3(\square)$. (a) Conditions are the same as for entry 2 of Table 2. (b) Conditions are the same as for entry 2 of Table 2, except for a double $\mathrm{C}_{2} \mathrm{H}_{4}$ pressure (50 bars, ca. 1440 equiv).

In conclusion, these new catalytic experiments not only reproduce the basic findings reported in the previous contribution, ${ }^{12}$ but also show that higher and more reproducible results are obtained in the absence of a glass liner (a negative effect of $I_{2}$ under this conditions remains to be rationalized) and demonstrate that the catalyst does not degrade under these conditions and furthermore give additional insights into the kinetic profile of the catalyzed transformation.

\section{(b) Hydroamination with $\left[\mathrm{RhI}\left(\mathrm{PPh}_{3}\right)_{2}\right]_{2}$}

As stated in the Introduction, the presence of a reducing environment (ethylene, aniline) and of the $\mathrm{PPh}_{3}$ ligand presumably reduces the $\mathrm{RhCl}_{3} \cdot 3 \mathrm{H}_{2} \mathrm{O}$ precatalyst to a $\mathrm{Rh}^{\mathrm{I}}-\mathrm{PPh}_{3}$ complex. Furthermore, since the catalytic activity of $\mathrm{RhCl}_{3} \cdot 3 \mathrm{H}_{2} \mathrm{O}$ is best promoted by the iodide ion, we assume that the active species is a $\mathrm{Rh}^{\mathrm{I}}-\mathrm{I}$ complex. Indeed, iodide derivatives of $\mathrm{Rh}^{\mathrm{I}}$ can been prepared by salt metathesis from the chlorido analogues and an iodide salt. ${ }^{25}$ To test this hypothesis, we have carried out a catalytic run with the $\left[\mathrm{RhI}\left(\mathrm{PPh}_{3}\right)_{2}\right]_{2}$ complex as a pre-catalyst, both with and without the addition of excess free iodide in the form of the tetra- $n$-butylphosphonium salt. The results are shown in Table 3.

Table 3. Hydroamination of ethylene by aniline catalyzed by $\left[\mathrm{RhI}\left(\mathrm{PPh}_{3}\right)_{2}\right]_{2}{ }^{\mathrm{a}}$

\begin{tabular}{ccccccc}
\hline Run & I $^{-} /$Rh & Conv./\% & TON 1 & TON 2 & TON 3 & CE $^{\mathrm{b}}$ \\
\hline 7 & 65 & 74 & 144 & 116 & 0 & 377 \\
8 & - & 1 & 2 & 0 & 0 & 1
\end{tabular}

${ }^{\mathrm{a} C}$ Conditions: $\left[\mathrm{RhI}\left(\mathrm{PPh}_{3}\right)_{2}\right]_{2}(98.1 \mathrm{mg}, 0.13 \mathrm{mmol}$ of $\mathrm{Rh}), \mathrm{PhNH}_{2}\left(4.1 \mathrm{~mL}, 45.5 \mathrm{mmol}, 350\right.$ equiv), $\mathrm{C}_{2} \mathrm{H}_{4}$ (25 bars; ca. 770 equiv), $150^{\circ} \mathrm{C}, 96 \mathrm{~h} .{ }^{\mathrm{b}} \mathrm{CE}$ (catalytic efficiency) $=\mathrm{TON} 1+2(\mathrm{TON} 2)+2(\mathrm{TON} 3)$.

Comparison of the result of run 7 with that of run 2 (Table 2) indicates that $\left[\mathrm{RhI}\left(\mathrm{PPh}_{3}\right)_{2}\right]_{2}$ indeed leads to efficient catalysis, although the activity is slightly lower than that obtained from the same amount of 
$\mathrm{RhCl}_{3} \cdot 3 \mathrm{H}_{2} \mathrm{O}$. This difference is probably related to parallel reactions that occur during the $\mathrm{RhCl}_{3} \cdot 3 \mathrm{H}_{2} \mathrm{O}$ catalyst reduction and conversion to the iodide system, which involve the chloride ions, ethylene, aniline and perhaps also $\mathrm{PPh}_{3}$, and produce other species that possibly further promote the catalysis. The water present in the $\mathrm{RhCl}_{3} \cdot 3 \mathrm{H}_{2} \mathrm{O}$ compound may also act as a catalysis promoter. The results strongly support the proposal that the active form of the hydroamination catalyst is indeed, as initially suspected, a $\mathrm{Rh}^{\mathrm{I}}$ species, because run 7 was carried out with a $\mathrm{Rh}^{\mathrm{I}}$ precatalyst and without any $\mathrm{I}_{2}$ additive. Note also that essentially no activity was obtained when the experiment was carried out in the absence of the iodide salt promoter (run 8). This results perfectly parallels that reported for the $\mathrm{RhCl}_{3} \cdot 3 \mathrm{H}_{2} \mathrm{O} / \mathrm{I}^{-}$ system. $^{12}$

We now report the results of our investigations of the coordination chemistry and the relative thermodynamic stability of various $\mathrm{Rh}^{\mathrm{I}}$ complexes, both in the chloride and iodide versions, in order to learn more about the equilibria that may take place for the catalytic species under the catalytic hydroamination conditions.

\section{(c) Chloride system}

As known in the literature, complex $\mathrm{RhCl}\left(\mathrm{PPh}_{3}\right)_{3}$ (Wilkinson's catalyst) equilibrates in solution with the dinuclear complex $\left[\mathrm{RhCl}\left(\mathrm{PPh}_{3}\right)_{2}\right]_{2}$ and free $\mathrm{PPh}_{3}$ to a different extent depending on solvent and concentration. ${ }^{23}$ Most of our NMR studies were carried out in $\mathrm{CD}_{2} \mathrm{Cl}_{2}$ at ca. $10^{-2} \mathrm{M}$ concentration, where this dissociation was visible albeit not extensive. A representative ${ }^{31} \mathrm{P}$ spectrum is shown in the supporting information (figure S1), indicating $<10 \%$ dissociation. Hence, the equilibrium shown in equation 1 is shifted to the left under our conditions, even in the absence of excess $\mathrm{PPh}_{3}$. The experiments that will be described further down, carried out starting from the pure dinuclear compound, were inspired by the observed changes to the small doublet ${ }^{31} \mathrm{P}\left\{{ }^{1} \mathrm{H}\right\}$ resonance of this compound $(\delta$ $51.50 \mathrm{~J}_{\mathrm{PRh}}=196 \mathrm{~Hz}$ ) when carrying out reactions on $\mathrm{RhCl}\left(\mathrm{PPh}_{3}\right)_{3}$. 
The reaction between complex $\mathrm{RhCl}\left(\mathrm{PPh}_{3}\right)_{3}$ and ethylene has already been studied, since it represents a key step of the olefin hydrogenation process catalyzed by Wilkinson's catalyst. ${ }^{23}$ It affords compound trans- $\mathrm{RhCl}\left(\mathrm{PPh}_{3}\right)_{2}\left(\mathrm{C}_{2} \mathrm{H}_{4}\right)$, which could be isolated, but the latter tends to lose ethylene to generate $\left[\mathrm{RhCl}\left(\mathrm{PPh}_{3}\right)_{2}\right]_{2}$, with which it is in rapid equilibrium (the ${ }^{1} \mathrm{H}$ NMR shows only one resonance for free and coordinated $\mathrm{C}_{2} \mathrm{H}_{4}$, the position of which shifts as a function of the $\mathrm{C}_{2} \mathrm{H}_{4}$ excess). These results indicate a relatively comparable stability for the two sides of equation 2 . We recall these literature results here because we will compare them later with other equilibria and with the results of computational investigations of relative thermodynamic stability.

$$
\left[\mathrm{RhCl}\left(\mathrm{PPh}_{3}\right)_{2}\right]_{2}+2 \mathrm{C}_{2} \mathrm{H}_{4} \rightleftarrows 2 \text { trans- } \mathrm{RhCl}\left(\mathrm{PPh}_{3}\right)_{2}\left(\mathrm{C}_{2} \mathrm{H}_{4}\right)
$$

Exposure of $\mathrm{RhCl}\left(\mathrm{PPh}_{3}\right)_{3}$ to aniline, up to a large excess (> 10 equiv) yielded no observable changes in the ${ }^{31} \mathrm{P}\left\{{ }^{1} \mathrm{H}\right\}$ NMR spectrum, except for a broadening of the doublet resonance of $\left[\mathrm{RhCl}\left(\mathrm{PPh}_{3}\right)_{2}\right]_{2}$. For this reason, the interaction of aniline was studied more in detail starting from the pure dinuclear complex. The addition of a large excess of $\mathrm{PhNH}_{2}$ (up to 65 equiv) did not reveal any new ${ }^{31} \mathrm{P}\left\{{ }^{1} \mathrm{H}\right\}$ resonance but shows a significant broadening without major shifting of the resonance of compound $\left[\mathrm{RhCl}\left(\mathrm{PPh}_{3}\right)_{2}\right]_{2}$, as illustrated in Figure 2, suggesting a fast exchange between the reagents and the product (equation 3), strongly shifted to the reagents. Estimating a maximum amount of $1 \%$ product, given the conditions of temperature and concentrations, we can estimate that the product is at least 5.5 $\mathrm{kcal} \mathrm{mol}^{-1}$ higher in free energy than the dinuclear precursor. On the other hand, the line broadening $\left(w_{1 / 2}\right.$ ca. $\left.150 \mathrm{~Hz}\right)$ gives us information on the pseudo $1^{\text {st }}$ order exchange rate constant, yielding an estimated barrier of $14 \mathrm{kcal} \mathrm{mol}^{-1}$ for the aniline addition process. 


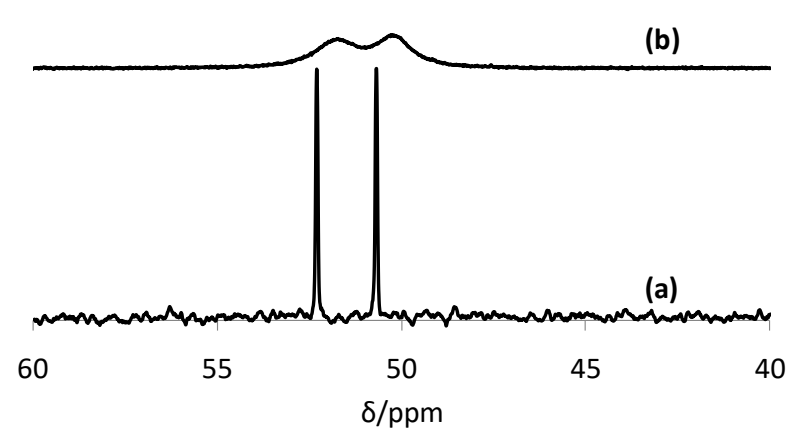

Figure 2. ${ }^{31} \mathrm{P}\left\{{ }^{1} \mathrm{H}\right\}$ study in $\mathrm{CD}_{2} \mathrm{Cl}_{2}$ of the interaction between $\left[\mathrm{RhCl}\left(\mathrm{PPh}_{3}\right)_{2}\right]_{2}(\mathrm{c}=0.027 \mathrm{M})$ and $\mathrm{PhNH}_{2}$ in $\mathrm{CD}_{2} \mathrm{Cl}_{2}$. (a) Without $\mathrm{PhNH}_{2}$. (b) With 65 equiv of $\mathrm{PhNH}_{2}$. The difference in noise level is caused by a much larger number of accumulations for spectrum (b).

$$
\left[\mathrm{RhCl}\left(\mathrm{PPh}_{3}\right)_{2}\right]_{2}+2 \mathrm{PhNH}_{2} \longleftrightarrow 2 \mathrm{RhCl}\left(\mathrm{PPh}_{3}\right)_{2}\left(\mathrm{PhNH}_{2}\right)
$$

Given the difficulty in obtaining a stable amine derivative, we have oriented our investigation toward a more basic amine as a model system. The reaction of $\left[\mathrm{RhCl}\left(\mathrm{PPh}_{3}\right)_{2}\right]_{2}$ with $\mathrm{Et}_{2} \mathrm{NH}$ gave rise to a new product, cis- $\mathrm{RhCl}\left(\mathrm{PPh}_{3}\right)_{2}\left(\mathrm{Et}_{2} \mathrm{NH}\right)$. The ${ }^{31} \mathrm{P}\left\{{ }^{1} \mathrm{H}\right\}$ spectrum of the product of reaction 4 is shown in Figure 3. The two resonances in the form of doublets of doublets clearly indicate the cis stereochemistry, showing a mutual (PP) coupling of $47.5 \mathrm{~Hz}$ and couplings to the $\mathrm{Rh}$ nucleus by $207 \mathrm{~Hz}$ for the resonance at $\delta 55.0$ and by 167 for that at $\delta 48.3$. Note that no starting material remains visible in this spectrum ( $c f$. Figure 2) and no other product peak is visible, notably there is no doublet that could indicate the formation of a trans isomer. The small signals flanking the doublet of doublets centered at $\delta$ 48.3 is the doublet of triplets of a small amount of $\mathrm{RhCl}\left(\mathrm{PPh}_{3}\right)_{3}$ contaminant (cf. Figure $\mathrm{S} 1$; the corresponding doublet of doublets at $\delta$ 31.2, not shown in Figure 3, is also visible in the spectrum). Resonances of free $\mathrm{PPh}_{3}$ and $\mathrm{Ph}_{3} \mathrm{PO}$ are also observed in this spectrum. The ${ }^{1} \mathrm{H}$ spectrum shows, in addition to the large and unresolved multiplet resonance of the $\mathrm{PPh}_{3}$ ligands in the aromatic region, broad resonances of the amine $\mathrm{CH}_{2}$ and $\mathrm{CH}_{3}$ protons at $\delta 3.15$ and 1.60 . In the presence of excess $\mathrm{NHEt}_{2}$, these resonances remain distinguished from those of free $\mathrm{NHEt}_{2}$, indicating slow exchange, but become sharper and notably the $\mathrm{CH}_{2}$ resonance pattern is more complex than a binomial quartet, as 
expected since these protons become inequivalent (diastereotopic) upon coordination.

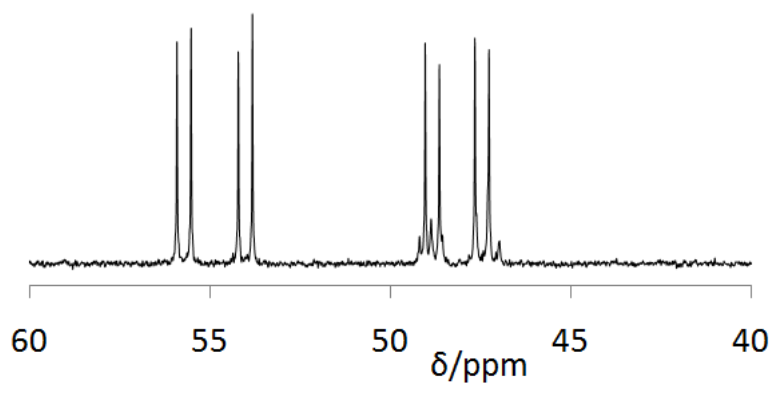

Figure 3. ${ }^{31} \mathrm{P}\left\{{ }^{1} \mathrm{H}\right\}$ spectrum in $\mathrm{CD}_{2} \mathrm{Cl}_{2}$ of cis- $\mathrm{RhCl}\left(\mathrm{PPh}_{3}\right)_{2}\left(\mathrm{Et}_{2} \mathrm{NH}\right)$, obtained from $\left[\mathrm{RhCl}\left(\mathrm{PPh}_{3}\right)_{2}\right]_{2}$ and $\mathrm{Et}_{2} \mathrm{NH}$ (5 equiv).

A parallel IR study in the NH stretching vibration region showed the complete consumption of Et ${ }_{2} \mathrm{NH}$ $\left(v_{\mathrm{NH}}=3327 \mathrm{~cm}^{-1}, \Delta v_{1 / 2}=45 \mathrm{~cm}^{-1} \varepsilon=2 \mathrm{~L} \mathrm{~mol}^{-1} \mathrm{~cm}^{-1}\right)$ at a $1: 1 \mathrm{Et}_{2} \mathrm{NH} / \mathrm{Rh}$ ratio and the appearance of a new narrower $v_{\mathrm{NH}}$ band assigned to the coordinated amine $\left(v_{\mathrm{NH}}=3279 \mathrm{~cm}^{-1}, \Delta v_{1 / 2}=12 \mathrm{~cm}^{-1}\right)$, see Figure 4. This behaviour is similar to that recently described for the $\operatorname{PtBr}_{2}\left(\mathrm{C}_{2} \mathrm{H}_{4}\right)\left(\mathrm{NHEt}_{2}\right)$ complex. $^{8}$ Addition of $\mathrm{Et}_{2} \mathrm{NH}$ beyond a $\mathrm{Et}_{2} \mathrm{NH} / \mathrm{Rh}$ ratio of 2 reduced the intensity of this new band in favour of yet another band at $3263 \mathrm{~cm}^{-1}\left(\Delta v_{1 / 2}=26 \mathrm{~cm}^{-1}\right)$, which can be attributed to the $v_{\mathrm{NH}}$ vibrations of both coordinated and hydrogen bonded amine in a cis- $\mathrm{RhCl}\left(\mathrm{PPh}_{3}\right)_{2}\left(\mathrm{Et}_{2} \mathrm{NH}\right) \cdot \mathrm{Et}_{2} \mathrm{NH}$ adduct on the basis of DFT calculations (vide infra). This evidence illustrates the presence of an H-bonding equilibrium, as detailed in equations 4 and 5 .

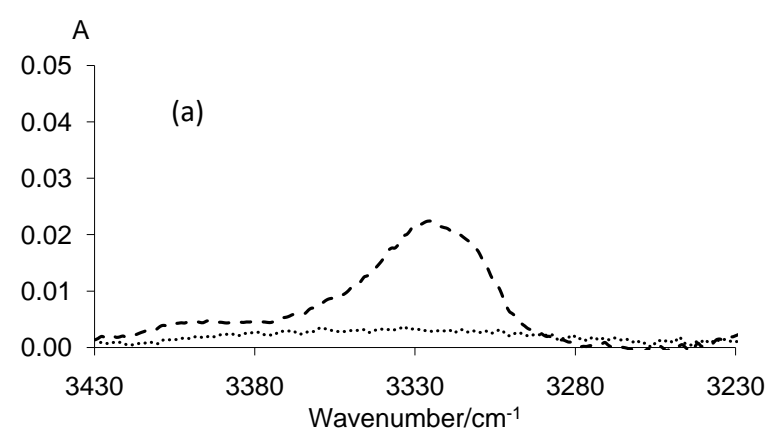




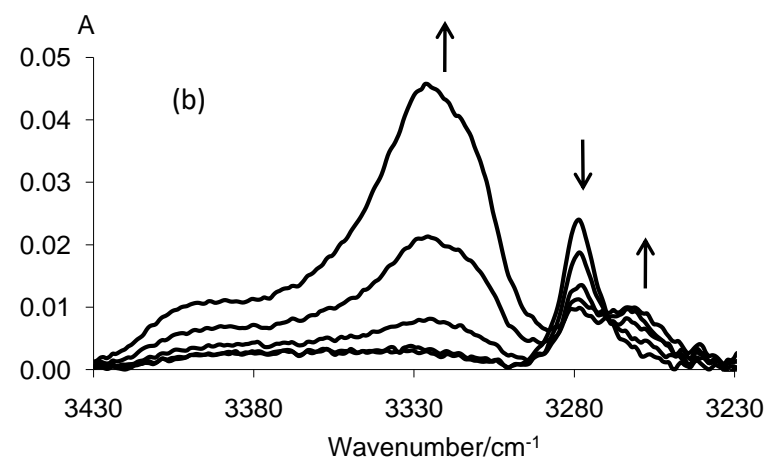

Figure 4. Infrared study of the reaction of $\left[\mathrm{RhCl}\left(\mathrm{PPh}_{3}\right)_{2}\right]_{2}$ with $\mathrm{NHEt}_{2}$ in $\mathrm{CH}_{2} \mathrm{Cl}_{2}$ (pathlength $=2.2$ $\mathrm{mm})$. (a) Spectra of $\left[\mathrm{RhCl}\left(\mathrm{PPh}_{3}\right)_{2}\right]_{2}\left(\mathrm{c}=6 \cdot 10^{-3} \mathrm{M}\right)$ (dotted line) and $\mathrm{NHEt}_{2}(\mathrm{c}=0.05 \mathrm{M}$, dashed line). (b) Spectra of a $6 \cdot 10^{-3} \mathrm{M}$ solution of $\left[\mathrm{RhCl}\left(\mathrm{PPh}_{3}\right)_{2}\right]_{2}$ after addition of $\mathrm{NHEt}_{2}$ with the successive concentrations $(6,12,24,60$ and 120$) \cdot 10^{-3} \mathrm{M}$.

$$
\begin{aligned}
& {\left[\mathrm{RhCl}\left(\mathrm{PPh}_{3}\right)_{2}\right]_{2}+2 \mathrm{Et}_{2} \mathrm{NH} \longrightarrow 2 \text { cis }-\mathrm{RhCl}\left(\mathrm{PPh}_{3}\right)_{2}\left(\mathrm{Et}_{2} \mathrm{NH}\right)}
\end{aligned}
$$

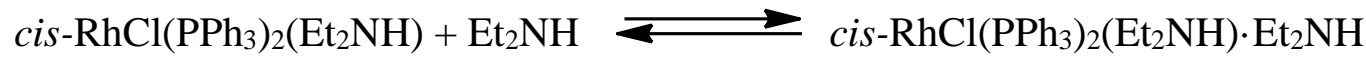

The literature is rather poor of reports of CO-free amine complexes of rhodium(I). A complex similar to $c i s-\mathrm{RhCl}\left(\mathrm{PPh}_{3}\right)_{2}\left(\mathrm{Et}_{2} \mathrm{NH}\right)$ was obtained by the same strategy (equation 4$)$ with a substituted pyridine in place of $\mathrm{Et}_{2} \mathrm{NH}$, affording again a single product with cis geometry as confirmed by an X-ray structural analysis, but no ${ }^{31} \mathrm{P}$ NMR data were reported. ${ }^{44}$ Complex $\mathrm{RhCl}\left(\mathrm{PPh}_{3}\right)_{2}\left(\mathrm{Et}_{2} \mathrm{NSiMe}_{3}\right)$, obtained by ligand exchange from $\mathrm{RhCl}\left(\mathrm{PPh}_{3}\right)_{3}$, on the other hand, shows only a single ${ }^{31} \mathrm{P} \mathrm{NMR}$ resonance in agreement with a trans geometry. ${ }^{45}$ It is possible in principle that the non-equivalence of the ${ }^{31} \mathrm{P}$ resonances for $\mathrm{RhCl}\left(\mathrm{PPh}_{3}\right)_{2}\left(\mathrm{Et}_{2} \mathrm{NH}\right)$ is caused by restricted rotation around the $\mathrm{Rh}-\mathrm{N}$ in a trans structure, however in this case the $\mathrm{RhCl}\left(\mathrm{PPh}_{3}\right)_{2}\left(\mathrm{Et}_{2} \mathrm{NSiMe}_{3}\right)$ analogue would also be expected to have restricted rotation, since the amine is bulkier, leading to inequivalent $\mathrm{P}$ nuclei. We prefer to believe in an electronic effect of the amine ligand (the preference of a cis structure has also been confirmed by DFT calculations, vide infra). In further support of the assigned cis structure, the two ${ }^{1} \mathrm{~J}_{\mathrm{PRh}}$ and the ${ }^{2} \mathrm{~J}_{\mathrm{PP}}$ values observed for $\mathrm{RhCl}\left(\mathrm{PPh}_{3}\right)_{2}\left(\mathrm{Et}_{2} \mathrm{NH}\right)$ are very close to those reported for two different conformers of $\mathrm{RhCl}\left(\mathrm{Ph}_{2} \mathrm{PCH}_{2} \mathrm{CH}_{2} \mathrm{PPh}_{2}\right)\left[\mathrm{N}\left(\mathrm{CH}_{2} \mathrm{Ph}\right)=\mathrm{C}(\mathrm{Me})\left(\mathrm{C}_{6} \mathrm{H}_{4}-4-\mathrm{OMe}\right)\right]$ where the $c$ is conformation is enforced by 
the chelating nature of the diphosphine $(203.5,166.9$ and 42.9 for one; $199.4, \sim 171$ and 43.5 for the other), with the same pattern (higher ${ }^{1} \mathrm{~J}_{\mathrm{PRh}}$ for the lower field resonance). ${ }^{46}$ We have attempted to crystallize the $\mathrm{Et}_{2} \mathrm{NH}$ adduct and indeed single crystals were obtained from a solution that contained a large excess of $\mathrm{NHEt}_{2}$ ( 5 equiv). However, the reversibility of equation 4 and the lower solubility of the dinuclear products led to the crystallization of the starting material. The molecular structure of $\left[\mathrm{RhCl}\left(\mathrm{PPh}_{3}\right)_{2}\right]_{2}$ has previously been reported in a habit containing an interstitial molecule of ethyl acetate per dimer, ${ }^{47}$ whereas a crystal containing a disordered dichloromethane molecule was obtained under our conditions. A view of the molecule is reported in Figure 5. The structural details are in good agreement with those of the ethyl acetate solvate and no further comment on this structure is warranted.

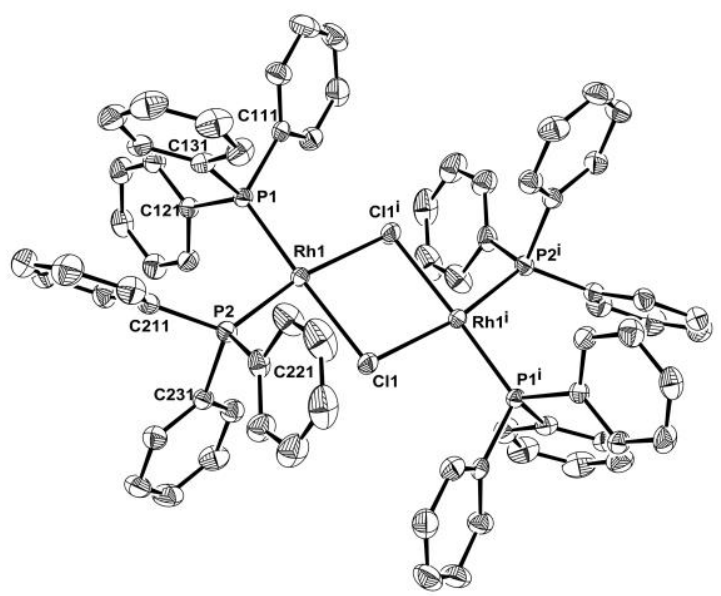

Figure 5. Molecular view of $\left[\mathrm{RhCl}\left(\mathrm{PPh}_{3}\right)_{2}\right]_{2}$ with the atom-labelling scheme. Displacement ellipsoids are drawn at the $50 \%$ probability level. $\mathrm{H}$ atoms have been omitted for clarity. Relevant bond distances $(\AA)$ and angles $\left(^{\circ}\right)$ : Rh-Cl, 2.4309(6); Rh-Cl ${ }^{\mathrm{i}}, 2.3967(6)$; Rh-P1, 2.2021(6); Rh-P2, 2.2168(6). P1-Rh-P2, 96.05(2); P1-Rh-C11, 176.23(2); P1-Rh-Cl1 ${ }^{\mathrm{i}}$, 95.24(2); P2-Rh-C11, 87.33(2); P2-Rh-Cl1 ${ }^{\mathrm{i}}$, 168.01(2); Cl1-Rh-Cl1 ${ }^{\mathrm{i}}, 81.51(2)$; Rh-Cl1-Rhi, 98.49(2). Symmetry transformations used to generate equivalent atoms: (i) $-\mathrm{x}+2,-\mathrm{y}+1,-\mathrm{z}$

In addition to $\mathrm{PPh}_{3}, \mathrm{C}_{2} \mathrm{H}_{4}$ and $\mathrm{PhNH}_{2}$, the hydroamination catalytic mixture also contains a halide salt. The study of the interaction between $\mathrm{RhCl}\left(\mathrm{PPh}_{3}\right)_{3}$ or $\left[\mathrm{RhCl}\left(\mathrm{PPh}_{3}\right)_{2}\right]_{2}$ and a halide salt was limited to chloride, introduced as the $n$-butylammonium salt, $n \mathrm{Bu}_{4} \mathrm{NCl}$, in order to avoid the complication of mixed halide systems. The corresponding iodide system will be examined below. To put the maximum 
chances on our side, we studied the addition of $\mathrm{Cl}^{-}$to the thermodynamically less stable dinuclear complex $\left[\mathrm{RhCl}\left(\mathrm{PPh}_{3}\right)_{2}\right]_{2}$, expecting to observe the product of equilibrium 6 . However, the ${ }^{31} \mathrm{P}$ NMR spectrum of the solution, in the presence of as much as 10 equiv of $n \mathrm{Bu} 4 \mathrm{Cl}$, still showed the doublet resonance of the dinuclear starting material as the dominant resonance in the spectrum, unshifted and unbroadened relative to that of the pure starting material. Several other minor peaks, besides a peak of $\mathrm{Ph}_{3} \mathrm{PO}$, were also visible (spectrum shown in Figure S2) but it is impossible to assign any of them with certainty to the expected product of equation 6 . The solution also shows instability, as additional small resonances became visible upon keeping the solution under argon for several hours. The resonance of $\left[\mathrm{RhCl}\left(\mathrm{PPh}_{3}\right)_{2}\right]_{2}$ always remained the dominant one, however. This experiment allow us to at least conclude that equilibrium 6, if any $\left[\mathrm{RhCl}_{2}\left(\mathrm{PPh}_{3}\right)_{2}\right]^{-}$product is formed at all, must be heavily shifted to the left hand side. Note that, on the other hand, the reaction of $\left[\mathrm{RhCl}(\mathrm{CO})_{2}\right]_{2}$ with chloride generates $\left[\mathrm{RhCl}_{2}(\mathrm{CO})_{2}\right]^{-}$quantitatively. ${ }^{48}$

$$
\left[\mathrm{RhCl}\left(\mathrm{PPh}_{3}\right)_{2}\right]_{2}+2 \mathrm{Cl}^{-} \longleftrightarrow 2\left[\mathrm{RhCl}_{2}\left(\mathrm{PPh}_{3}\right)_{2}\right]^{-}
$$

\section{(d) Iodide system}

Although compound $\mathrm{RhI}\left(\mathrm{PPh}_{3}\right)_{3}$ is known, ${ }^{23}$ its X-ray structure has apparently never been reported. The only reported structure with a $\mathrm{Rh}^{\mathrm{I}} \mathrm{IP}_{3}$ coordination environment is apparently that of compound $\operatorname{RhI}($ diop $)\left(\mathrm{PPh}_{3}\right) .{ }^{49}$ Compound $\mathrm{RhI}\left(\mathrm{PPh}_{3}\right)_{3}$ crystallizes with the full molecule in the asymmetric unit in the orthorhombic space group Pna2 $2_{1}$ A view of the molecule is shown in Figure 6. The presence of three sterically encumbering $\mathrm{PPh}_{3}$ ligands forces the structure to deviate from the preferred square planar configuration toward a butterfly arrangement (trans angles around $160^{\circ}$ ). The same effect was previously noted for different polymorphs of the related $\mathrm{RhCl}\left(\mathrm{PPh}_{3}\right)_{3}$ compound. ${ }^{50}$ The $\mathrm{Rh}-\mathrm{P}$ distances in the iodide structure compare well with those in the two different chloride structures, with the two phosphine ligands trans to each other showing slightly longer distances relative to that trans to the 
halide. The latter has a marginally longer distance than the same ligand in the two chloride structures [2.225(4) and 2.214(4) $\AA$ ]. The Rh-I distance is shorter relative to the above mentioned diop complex $[2.704(1) \AA] .{ }^{49}$

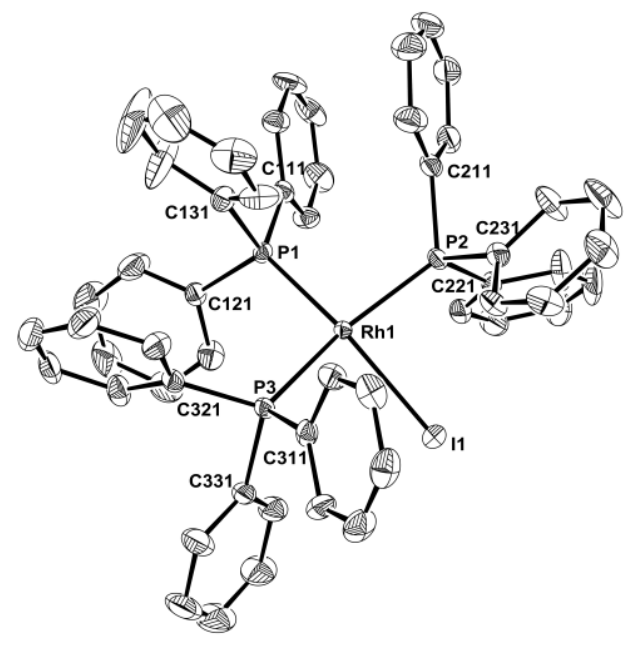

Figure 6. Molecular view of $\mathrm{RhI}\left(\mathrm{PPh}_{3}\right)_{3}$ with the atom-labelling scheme. Displacement ellipsoids are drawn at the $50 \%$ probability level. $\mathrm{H}$ atoms have been omitted for clarity. Relevant bond distances $(\AA)$ and angles $\left(^{\circ}\right)$ : Rh-I, 2.6840(3); Rh-P1, 2.2303(7); Rh-P2, 2.2937(7); Rh-P3, 2.3239(7). I-Rh-P1, 163.53(2); I-Rh-P2, 86.09(2); I-Rh-P3, 86.76(2); P1-Rh-P2, 97.38(3); P1-Rh-P3, 95.39(3); P2-Rh-P3, $157.89(3)$.

As already described in the literature, complex $\mathrm{RhI}\left(\mathrm{PPh}_{3}\right)_{3}$ equilibrates in solution with the dinuclear species $\left[\mathrm{RhI}\left(\mathrm{PPh}_{3}\right)_{2}\right]_{2}$ and free $\mathrm{PPh}_{3}$, like the chloride analogue. The dinuclear species is favored to a greater extent for the iodide system and indeed the best preparation method of the dinuclear complex is by $\mathrm{PPh}_{3}$ dissociation under thermal conditions in a solvent where the dinuclear product is less soluble and precipitates. ${ }^{24}$ The literature also shows that $\mathrm{PPh}_{3}$ dissociation is faster for $\mathrm{RhI}\left(\mathrm{PPh}_{3}\right)_{3}$ than for the corresponding chloride, since the ${ }^{31} \mathrm{P}$ resonances are broad at room temperature ${ }^{25}$ and become sharper upon cooling. All these observations, reproduced in our hands, suggest that the $\mathrm{Rh}-\mathrm{PPh}_{3}$ interaction is weaker in the iodide system.

The reaction of $\left[\mathrm{RhI}\left(\mathrm{PPh}_{3}\right)_{2}\right]_{2}$ with $\mathrm{C}_{2} \mathrm{H}_{4}$ takes place readily in dichloromethane and more slowly in toluene, to afford trans- $\mathrm{RhI}\left(\mathrm{PPh}_{3}\right)_{2}\left(\mathrm{C}_{2} \mathrm{H}_{4}\right)$ selectively (equation 7$)$, as shown by the presence of only one 
doublet resonance in the ${ }^{31} \mathrm{P}$ NMR spectrum at $\delta 35.8\left({ }^{1} \mathrm{~J}_{\mathrm{P}-\mathrm{Rh}}=124 \mathrm{~Hz}\right)$ in $\mathrm{CD}_{2} \mathrm{Cl}_{2}$. The possibility that a halogen exchange has occurred with the chlorinated solvent to yield trans- $\mathrm{RhCl}\left(\mathrm{PPh}_{3}\right)_{2}\left(\mathrm{C}_{2} \mathrm{H}_{4}\right)$, besides being against the HSAB principle, is categorically excluded because the same experiment run in toluene- $d_{8}$ gave a doublet resonance at $\delta 36.4\left({ }^{1} \mathrm{~J}_{\mathrm{P}-\mathrm{Rh}}=125 \mathrm{~Hz}\right)$, whereas the corresponding experiment using $\left[\mathrm{RhCl}\left(\mathrm{PPh}_{3}\right)_{2}\right]_{2}$ in place of $\left[\mathrm{RhI}\left(\mathrm{PPh}_{3}\right)_{2}\right]_{2}$ gave a doublet resonance at $\delta 34.9\left(\mathrm{~d},{ }^{1} \mathrm{~J}_{\mathrm{P}-\mathrm{Rh}} 129 \mathrm{~Hz}\right)$. The coupling constant in the $\mathrm{CD}_{2} \mathrm{Cl}_{2}$ spectrum matches well with that obtained for the iodide system but not with that obtained for the chloride system in toluene- $d_{8}$. The ${ }^{1} \mathrm{H}$ spectrum of trans$\mathrm{RhI}\left(\mathrm{PPh}_{3}\right)_{2}\left(\mathrm{C}_{2} \mathrm{H}_{4}\right)$ shows a broad resonance for the ethylene ligand, like that reported in the literature ${ }^{23}$ for the corresponding chlorido derivative. Note that this complex could not be isolated and an NMR spectrum was not reported in the original study by Wilkinson et al., ${ }^{23}$ where its generation was attempted from $\mathrm{RhI}\left(\mathrm{PPh}_{3}\right)_{3}$. Our results and those already available in the literature suggest that the ethylene binding constant to $\left[\mathrm{RhI}\left(\mathrm{PPh}_{3}\right)_{2}\right]$ is smaller than for the chlorido analogue.

$$
\left[\mathrm{RhI}\left(\mathrm{PPh}_{3}\right)_{2}\right]_{2}+2 \mathrm{C}_{2} \mathrm{H}_{4} \rightleftarrows 2 \text { trans- } \mathrm{RhI}\left(\mathrm{PPh}_{3}\right)_{2}\left(\mathrm{C}_{2} \mathrm{H}_{4}\right)
$$

Addition of aniline, even in large excess, to $\left[\mathrm{RhI}\left(\mathrm{PPh}_{3}\right)_{2}\right]_{2}$ did not lead to any spectral change and notably, contrary to the chlorido system, did not significantly broaden the ${ }^{31} \mathrm{P}$ resonance, suggesting that the energy gap between the reactant mixture and the putative $\mathrm{RhI}\left(\mathrm{PPh}_{3}\right)_{2}\left(\mathrm{PhNH}_{2}\right)$ product is greater than for to corresponding chlorido system. Addition of $\mathrm{Et}_{2} \mathrm{NH}$, on the other hand, resulted in reaction and formation of the expected cis- $\mathrm{RhI}\left(\mathrm{PPh}_{3}\right)_{2}\left(\mathrm{Et}_{2} \mathrm{NH}\right)$. The latter compound is characterized, like the above described chlorido analogue, by two doublets of doublets for the two inequivalent $\mathrm{PPh}_{3}$ ligands, see Figure 7. At variance with the chlorido system, the $\mathrm{Et}_{2} \mathrm{NH}$ addition process was not quantitative, resonances of the starting dinuclear complex remaining visible even after adding an excess amount of amine. The $\mathrm{J}_{\mathrm{PRh}}$ of the dinuclear compound in the two spectra of Figure 7 is the same $(190 \mathrm{~Hz}$; the spectra were taken at two different field strengths). 


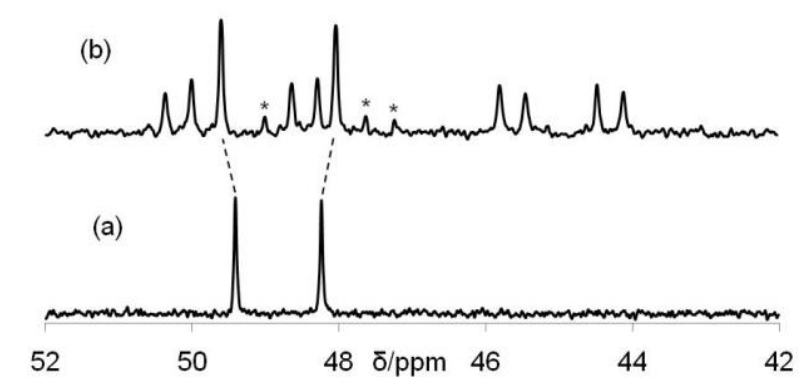

Figure 7. ${ }^{31} \mathrm{P}\left\{{ }^{1} \mathrm{H}\right\}$ NMR spectra of $\left[\mathrm{RhI}\left(\mathrm{PPh}_{3}\right)_{2}\right]_{2}$ in $\mathrm{CD}_{2} \mathrm{Cl}_{2}$ before (a) and after (b) the addition of 3 equiv of $\mathrm{Et}_{2} \mathrm{NH}$. The starred peaks are due to a trace amount of chlorido derivative, $\mathrm{RhCl}\left(\mathrm{PPh}_{3}\right)_{2}\left(\mathrm{NHEt}_{2}\right)(c f$. Figure 3).

The IR study of the reaction showed the consumption of the free amine $v_{\mathrm{NH}}$ band, accompanied by the appearance of the band of the coordinated amine at $v_{\mathrm{NH}}=3279 \mathrm{~cm}^{-1}\left(\Delta v_{1 / 2}=12 \mathrm{~cm}^{-1}\right)$. This frequency is identical to that of the chlorido analogue, showing a negligible effect of the halide nature on the N-H stretching frequency. However, further addition of $\mathrm{Et}_{2} \mathrm{NH}$ resulted in a much less significant change compared to the chlorido system. The lower frequency $v_{\mathrm{NH}}$ band of the $\left[\mathrm{RhI}\left(\mathrm{Et}{ }_{2} \mathrm{NH}\right)\left(\mathrm{PPh}_{3}\right)_{2}\right] \cdot \mathrm{Et}_{2} \mathrm{NH}$ adduct appeared in the spectrum only with a 10 fold excess of amine as a weak shoulder at ca $3260 \mathrm{~cm}^{-1}$, see Figure 8. This is in agreement with the computational results, showing less favourable formation of this adduct in case of iodide (vide infra).

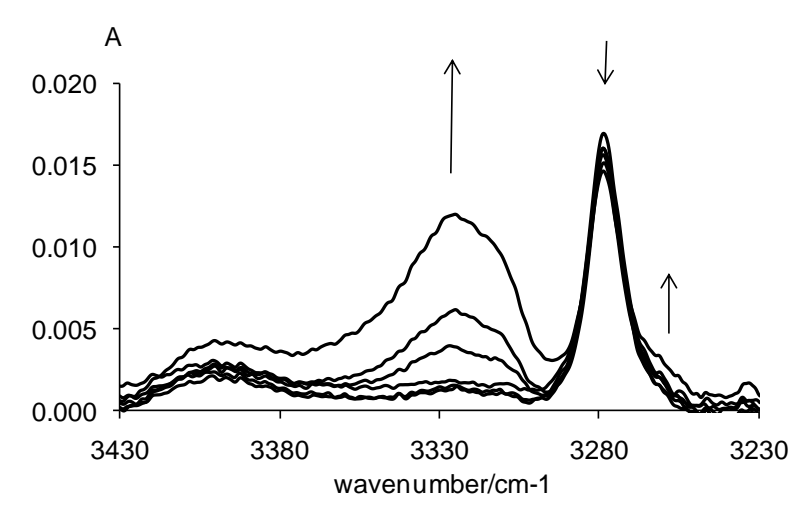

Figure 8. Infrared study of the reaction of $\left[\mathrm{RhI}\left(\mathrm{PPh}_{3}\right)_{2}\right]_{2}\left(\mathrm{c}=3 \cdot 10^{-3} \mathrm{M}\right)$ with $\mathrm{NHEt}_{2}$ in $\mathrm{CH}_{2} \mathrm{Cl}_{2}$ (pathlength $=2.2 \mathrm{~mm}$ ), after addition of NHEt $_{2}$ with the successive concentrations $(3,4.5,6,12,18$ and $30) \cdot 10^{-3} \mathrm{M}$. 
Finally, addition of $\mathrm{I}^{-}$(in the form of its $\mathrm{Bu}_{4} \mathrm{~N}^{+}$salt, up to 3 equiv per $\mathrm{Rh}$ ) to complex $\left[\mathrm{RhI}\left(\mathrm{PPh}_{3}\right)_{2}\right]_{2}$, like for the related experiment on the chloride system, resulted in no significant spectral change, indicating that equilibrium 8 is heavily shifted toward the left hand side. Like for the chlorido analogue, the corresponding dicarbonyl complex $\left[\mathrm{RhI}_{2}(\mathrm{CO})_{2}\right]^{-}$is a well known compound. ${ }^{48}$

$$
\left[\mathrm{RhI}\left(\mathrm{PPh}_{3}\right)_{2}\right]_{2}+2 \mathrm{I}^{-} \longleftrightarrow 2\left[\mathrm{RhI}_{2}\left(\mathrm{PPh}_{3}\right)_{2}\right]^{-}
$$

\section{(e) Treatment of $\mathrm{RhCl}_{3} \cdot 3 \mathrm{H}_{2} \mathrm{O}$ with $\mathrm{PPh}_{3}$, Bu $4 \mathrm{NI}_{\text {I }}$ and aniline}

A final spectroscopic investigation consisted of the ${ }^{31} \mathrm{P}$ NMR study of a mixture prepared with all the catalytic components (except for ethylene) under conditions mimicking those of the catalysis, in order to gain further insights into the conversion of the $\mathrm{RhCl}_{3} \cdot 3 \mathrm{H}_{2} \mathrm{O}$ precatalyst into the active catalyst. Excluding ethylene allows the reaction to be carried out in simple glassware (the boiling point of aniline is $184.13{ }^{\circ} \mathrm{C}$ ). Thus, a mixture containing $\mathrm{RhCl}_{3} \cdot 3 \mathrm{H}_{2} \mathrm{O}, \mathrm{PPh}_{3}, n \mathrm{Bu} 4 \mathrm{PI}$ and $\mathrm{PhNH}_{2}$ in a 1:2:16:88 ratio was kept at $150^{\circ} \mathrm{C}$ for $16 \mathrm{~h}$, even though no change of color was noted after the first 10 min of heating. The $n \mathrm{Bu}_{4} \mathrm{PI}: \mathrm{PhNH}_{2}$ ratio in this experiment was identical to that of the catalytic runs, but the $\mathrm{Rh}$ and $\mathrm{PPh}_{3}$ concentrations were ca. 4 times higher in order to facilitate the ${ }^{31} \mathrm{P}$ NMR measurement of the reaction products in the presence of the large excess of $n \mathrm{Bu}_{4} \mathrm{P}^{+}$ion. The $n \mathrm{Bu}_{4} \mathrm{P}^{+}$resonance was indeed by far the most intense one in the spectrum, but was accompanied by two major and relatively broad peaks, which account for most of the $\mathrm{PPh}_{3}$ intensity, a stronger one at $\delta 52.0$ and a smaller one at $\delta 50.6$ (see Figure 9). The spectrum also showed a large number of other very weak resonances revealing the formation of many other products, none of which could be identified except $\mathrm{Ph}_{3} \mathrm{PO}$. 


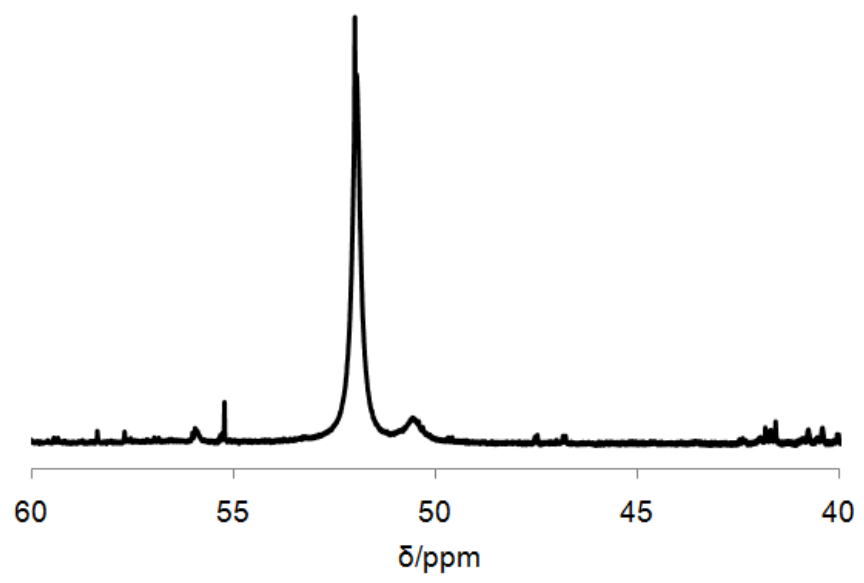

Figure 9. Excerpt of the ${ }^{31} \mathrm{P}\left\{{ }^{1} \mathrm{H}\right\}$ NMR spectrum of the final mixture generated from $\mathrm{RhCl}_{3} \cdot 3 \mathrm{H}_{2} \mathrm{O}$, $\mathrm{PPh}_{3}, n \mathrm{Bu} 4 \mathrm{PI}$ and $\mathrm{PhNH}_{2}$ in a $1: 2: 16: 88$ ratio at $150^{\circ} \mathrm{C}$.

Comparison of chemical shift and linewidth indicates that the major product $(\delta$ 52.0) is $\left[\mathrm{RhCl}\left(\mathrm{PPh}_{3}\right)_{2}\right]_{2}$ (cf. Figure 2). The presence of the large excess of aniline is responsible for the resonance broadening as discussed above. The dinuclear iodide analogue, $\left[\mathrm{RhI}\left(\mathrm{PPh}_{3}\right)_{2}\right]_{2}$, does not appear to be present, since it should generate an unbroadened resonance centered at $\delta 48.8$ (cf. Figure 7). It seems therefore reasonable to assume that the small resonance at $\delta 50.6$ belongs to a mixed-halido species, $\mathrm{Rh}_{2}(\mathrm{I})(\mathrm{Cl})\left(\mathrm{PPh}_{3}\right)_{4}$, broadened by exchange with aniline like the chlorido dimer and unlike the iodido dimer.

The results of this experiment confirm therefore that $\mathrm{RhCl}_{3} \cdot 3 \mathrm{H}_{2} \mathrm{O}$ is reduced to $\mathrm{Rh}^{\mathrm{I}}$ under catalytic conditions in the presence of $\mathrm{PPh}_{3}$, aniline and iodide ions but reveal that no extensive halide exchange has taken place and the chloride dinuclear species $\left[\mathrm{RhCl}\left(\mathrm{PPh}_{3}\right)_{2}\right]_{2}$ is the major reaction product, at least after cooling the mixture back to room temperature. The lack of extensive halide exchange may result from thermodynamic (the relative amount of iodide used here is 4 times less than in the catalytic run, but still in quite large excess relative to $\mathrm{Rh}$ ) or kinetic factors. We believe that the reason is thermodynamic. In support of this argument, we note that $\mathrm{Cl} / \mathrm{I}$ halide exchange processes have been shown to favour the chlorido species also in other cases when carried out in the presence of soluble salts (e.g. $\mathrm{CpMoI}_{2}\left(\mathrm{PMe}_{3}\right)_{2}$ to $\mathrm{CpMoICl}\left(\mathrm{PMe}_{3}\right)_{2}$ and $\mathrm{CpMoCl}_{2}\left(\mathrm{PMe}_{3}\right)_{2}$ with $\mathrm{PPNCl} / \mathrm{CH}_{2} \mathrm{Cl}_{2} ;{ }^{.51} \mathrm{MoOI}_{2}\left(\mathrm{PMe}_{3}\right)_{3}$ 
to $\mathrm{MoOICl}\left(\mathrm{PMe}_{3}\right)_{3}$ and $\mathrm{MoOCl}_{2}\left(\mathrm{PMe}_{3}\right)_{3}$ with $n \mathrm{Bu} 4 \mathrm{NCl} /$ acetone $\left.^{52}\right)$ whereas exchange in the opposite direction occurs in the presence of partially soluble alkali metal salts, presumably because of the lower solubility of the alkali metal chloride (e.g. $\mathrm{CpMoCl}_{2}\left(\mathrm{PMe}_{3}\right)_{2}$ to $\mathrm{CpMoICl}\left(\mathrm{PMe}_{3}\right)_{2}$ and $\mathrm{CpMoI}_{2}\left(\mathrm{PMe}_{3}\right)_{2}$ with $\mathrm{NaI} / \mathrm{THF} ;{ }^{53} \mathrm{MoOCl}_{2}\left(\mathrm{PMe}_{3}\right)_{3}$ to $\mathrm{MoOICl}\left(\mathrm{PMe}_{3}\right)_{3}$ and $\mathrm{MoOI}_{2}\left(\mathrm{PMe}_{3}\right)_{3}$ with $\mathrm{NaI} /$ acetone; ${ }^{.52}$ and of stronger relevance to this work, $\mathrm{RhCl}\left(\mathrm{PPh}_{3}\right)_{3}$ to $\left[\mathrm{RhI}\left(\mathrm{PPh}_{3}\right)_{2}\right]_{2}$ and free $\mathrm{PPh}_{3}$ with $\mathrm{LiI} /$ toluene $\left.{ }^{25}\right)$. DFT calculations have also been conducted to address this point (vide infra). At any rate, whatever the reason for the lack of halide exchange, the absence of a notable induction time in catalysis suggests that $\left[\mathrm{RhCl}\left(\mathrm{PPh}_{3}\right)_{2}\right]_{2}$ is an active precatalyst, without the need to be converted to the iodide analogue. The results do not exclude that the real catalyst is one of the very minor and unidentified by-products formed in the reaction. However, the catalytic activity demonstrated independently for $\left[\mathrm{RhI}\left(\mathrm{PPh}_{3}\right)_{2}\right]_{2} l_{\text {lends }}$ credence to the hypothesis that the dinuclear $\mathrm{Rh}^{\mathrm{I}}$ structure is indeed responsible for generating the active catalyst. If this is the case, then the promoting effect of iodide (much better than chloride) ${ }^{12}$ must operate at the level of higher-energy catalytic steps, rather than at the level of the resting state.

The most important conclusions to be drawn from this experiment is that the resting state of the catalytic cycle must be either $\left[\mathrm{RhCl}\left(\mathrm{PPh}_{3}\right)_{2}\right]_{2}$ or trans- $\mathrm{RhCl}\left(\mathrm{PPh}_{3}\right)_{2}\left(\mathrm{C}_{2} \mathrm{H}_{4}\right)$, because it is known from independent experiments reported here and in the literature that the reaction of $\left[\mathrm{RhCl}\left(\mathrm{PPh}_{3}\right)_{2}\right]_{2}($ or the iodido analogue) with ethylene is equilibrated but more favourable than the additions of aniline or halide ions.

\section{(f) DFT calculations}

No ligand simplification was made and the calculations were full QM, at the M06 level. The geometries of the dinuclear $\left[\mathrm{RhX}\left(\mathrm{PPh}_{3}\right)_{2}\right]_{2}$ systems $\left(\mathrm{X}=\mathrm{Cl}\right.$, I) and their ligand adducts $\left[\mathrm{RhX}\left(\mathrm{PPh}_{3}\right)_{2}(\mathrm{~L})\right]$ with $\mathrm{L}=\mathrm{PPh}_{3}, \mathrm{X}^{-}, \mathrm{PhNH}_{2}, \mathrm{Et}_{2} \mathrm{NH}$ and $\mathrm{C}_{2} \mathrm{H}_{4}$ have been optimized by DFT calculations. The optimized geometries are in good agreement with the available experimental structures, namely those of $\mathrm{RhCl}\left(\mathrm{PPh}_{3}\right)_{3}$ (orange allotrope) available in ref. ${ }^{50}$ and $\mathrm{RhI}\left(\mathrm{PPh}_{3}\right)_{3}$ reported in the present work. A 
comparison is available in Table 4. The largest deviation in the bond lengths is seen for the $\mathrm{Rh}-\mathrm{I}$ bond $(0.07 \AA)$, the others being within $0.05 \AA$, whereas the angles are all calculated within $2^{\circ}$ from the experimental values.

Table 4. Comparison between DFT optimized and experimental geometries (distances in $\AA$, angles in degrees)

\begin{tabular}{lcccc}
\hline & \multicolumn{2}{c}{$\mathrm{RhCl}\left(\mathrm{PPh}_{3}\right)_{3}$} & \multicolumn{2}{c}{$\mathrm{RhI}\left(\mathrm{PPh}_{3}\right)_{3}$} \\
\hline Rh-X & $\mathrm{DFT}$ & $\mathrm{Exp}^{\mathrm{a}}$ & $\mathrm{DFT}$ & $\mathrm{Exp}^{\mathrm{b}}$ \\
Rh-P(trans to X) & 2.258 & $2.225(4)$ & 2.278 & $2.2303(7)$ \\
Rh-P(trans to P) & 2.340 & $2.304(4)$ & 2.344 & $2.2937(7)$ \\
& 2.361 & $2.338(4)$ & 2.374 & $2.3239(7)$ \\
& 164.9 & $166.7(2)$ & 161.5 & $163.53(2)$ \\
X-Rh-P(trans) & 82.4 & $84.5(1)$ & 85.3 & $86.09(2)$ \\
X-Rh-P(cis) & 85.1 & $85.3(1)$ & 87.6 & $86.76(2)$ \\
& 156.5 & $159.1(2)$ & 157.7 & $157.89(3)$ \\
P-Rh-P(trans) & 101.6 & $97.7(1)$ & 99.3 & $97.38(3)$ \\
P-Rh-P(cis) & 95.7 & $96.4(2)$ & 94.1 & $95.39(3)$
\end{tabular}

${ }^{\mathrm{a}}$ Data from ref. ${ }^{50} .{ }^{\mathrm{b}}$ This work.

The calculated geometry of $\left[\mathrm{RhCl}\left(\mathrm{PPh}_{3}\right)_{2}\right]_{2}$ agrees with the experimental ones (both the previously reported ethyl acetate solvate ${ }^{47}$ and the dichloromethane solvate reported herein) in terms of bond lengths and angles, except for the bending at the $\mathrm{Rh}(\mu-\mathrm{Cl})_{2} \mathrm{Rh}$ bridge, whereas the experimental structures have a flat core. As a matter of fact, the preference for a bent or flat geometry for edgesharing square planar $d^{8}-d^{8}$ dimers rests on a delicate energetic balance, as previously discussed in detail. ${ }^{54}$ Very similar structures of $\left[\mathrm{RhCl}\left(\mathrm{PR}_{3}\right)_{2}\right]_{2}$ complexes have been shown to adopt either a flat (e.g. $\mathrm{P}_{i} \mathrm{Pr}_{3},{ }^{55}$ in addition to the above mentioned $\mathrm{PPh}_{3}$ structures) or bent (e.g. $\mathrm{PMe}_{3},{ }^{56} t \mathrm{Bu}_{2} \mathrm{PH}^{57}$ 
$\left(\mathrm{C}_{2} \mathrm{~F}_{5}\right)_{2} \mathrm{PCH}_{2} \mathrm{CH}_{2} \mathrm{P}\left(\mathrm{C}_{2} \mathrm{~F}_{5}\right)_{2},{ }^{58}$ and $\left.i \mathrm{Pr}_{2} \mathrm{PCH}_{2} \mathrm{CH}_{2}{\mathrm{P} i \mathrm{Pr}_{2}}^{59}\right)$ geometry, and the related $\left[\mathrm{RhF}\left(\mathrm{PPh}_{3}\right)_{2}\right]_{2}$ compound adopts either a flat ${ }^{60}$ or bent $^{61}$ geometry in different crystal habits. The calculations suggest preference for a bent geometry for an isolated $\left[\mathrm{RhCl}\left(\mathrm{PPh}_{3}\right)_{2}\right]_{2}$ molecule, at least at this level of theory, thus the experimental observation of a flat structure is probably the consequence of crystal packing effects.

The relative energies (both electronic and Gibbs free energies) for all $\mathrm{RhX}\left(\mathrm{PPh}_{3}\right)_{2}(\mathrm{~L})$ systems $(\mathrm{L}=$ $\mathrm{PPh}_{3}, \mathrm{X}^{-}, \mathrm{PhNH}_{2}, \mathrm{NHEt}_{2}$ and $\left.\mathrm{C}_{2} \mathrm{H}_{4} ; \mathrm{X}=\mathrm{Cl}, \mathrm{I}\right)$ are reported in Table 5. They are calculated with respect to the precursor complex $\left[\mathrm{RhX}\left(\mathrm{PPh}_{3}\right)_{2}\right]_{2}$ and free ligands $\mathrm{L}$ according to equation 9 . The direct comparison with the experimental data is complicated by several approximations, which are well known in the area of computational chemistry applied to condensed phase thermodynamics, the most important one being probably the use of unquenched translational and rotational modes for the estimation of the condensed phase entropy. Ion pairing effects (neglected in our calculation) may also affect the results for the ionic species.

$$
\left[\mathrm{RhX}\left(\mathrm{PPh}_{3}\right)_{2}\right]_{2}+2 \mathrm{~L} \rightarrow 2 \mathrm{RhX}\left(\mathrm{PPh}_{3}\right)_{2}(\mathrm{~L})
$$

Table 5. Various energetic parameters (in $\mathrm{kcal} / \mathrm{mol}$ ) of $\mathrm{RhX}\left(\mathrm{PPh}_{3}\right)_{2}(\mathrm{~L})$, relative to those of $1 / 2\left[\mathrm{RhX}\left(\mathrm{PPh}_{3}\right)_{2}\right]_{2}+\mathrm{L}\left(\mathrm{X}=\mathrm{Cl}, \mathrm{I} ; \mathrm{L}=\mathrm{PPh}_{3}, \mathrm{X}^{-}, \mathrm{PhNH}_{2}, \mathrm{Et}_{2} \mathrm{NH}\right.$ and $\left.\mathrm{C}_{2} \mathrm{H}_{4}\right)$.

$\begin{array}{llllll}\text { Compound } & \Delta \mathrm{E} & \Delta \mathrm{G}^{\mathrm{a}} & \Delta \mathrm{E}^{\mathrm{SMD}} & \Delta \mathrm{G}^{\mathrm{SMD}, \mathrm{b}} & \mathrm{G}_{\text {solv }}\end{array}$

(a) Chloride system

$\begin{array}{lccccc}\mathrm{RhCl}\left(\mathrm{PPh}_{3}\right)_{3} & -11.7 & -3.8 & -12.7 & -4.7 & -43.8 \\ \text { cis- }\left[\mathrm{RhCl}_{2}\left(\mathrm{PPh}_{3}\right)_{2}\right]^{-} & -6.8 & -9.1 & 8.2 & 5.8 & -73.6 \\ \text { trans- }\left[\mathrm{RhCl}_{2}\left(\mathrm{PPh}_{3}\right)_{2}\right]^{-} & -4.4 & -10.8 & 13.4 & 7.1 & -70.6 \\ \text { cis- } \mathrm{RhCl}\left(\mathrm{PPh}_{3}\right)_{2}\left(\mathrm{PhNH}_{2}\right) & -9.2 & -3.7 & -8.9 & -3.4 & -36.7 \\ \text { trans-RhCl}\left(\mathrm{PPh}_{3}\right)_{2}\left(\mathrm{PhNH}_{2}\right) & 3.2 & 6.4 & 1.1 & 4.3 & -39.0 \\ \text { cis- } \mathrm{RhCl}\left(\mathrm{PPh}_{3}\right)_{2}\left(\mathrm{Et}_{2} \mathrm{NH}\right) & -8.6 & -3.1 & -13.7 & -8.2 & -34.4\end{array}$




$\begin{array}{lccccc}\text { trans }-\mathrm{RhCl}\left(\mathrm{PPh}_{3}\right)_{2}\left(\mathrm{Et}_{2} \mathrm{NH}\right) & 5.2 & 9.2 & -1.8 & 2.3 & -36.2 \\ \text { cis }-\mathrm{RhCl}\left(\mathrm{PPh}_{3}\right)_{2}\left(\mathrm{C}_{2} \mathrm{H}_{4}\right) & -4.7 & -0.1 & -8.8 & -4.2 & -33.8 \\ \text { trans }-\mathrm{RhCl}\left(\mathrm{PPh}_{3}\right)_{2}\left(\mathrm{C}_{2} \mathrm{H}_{4}\right) & -6.2 & -3.3 & -10.4 & -7.4 & -33.8\end{array}$

(b) Iodide system

$\begin{array}{lccccc}\mathrm{RhI}\left(\mathrm{PPh}_{3}\right)_{3} & -9.3 & -0.8 & -9.5 & -1.0 & -42.8 \\ \text { cis- }\left[\mathrm{RhI}_{2}\left(\mathrm{PPh}_{3}\right)_{2}\right]^{-} & -0.9 & -3.8 & 8.9 & 6.0 & -69.1 \\ \text { trans- }\left[\mathrm{RhI}_{2}\left(\mathrm{PPh}_{3}\right)_{2}\right]^{-} & -0.6 & -5.5 & 11.5 & 6.5 & -66.9 \\ \text { cis-RhI }\left(\mathrm{PPh}_{3}\right)_{2}\left(\mathrm{PhNH}_{2}\right) & -6.4 & -1.3 & -5.3 & -0.2 & -35.6 \\ \text { trans-RhI }\left(\mathrm{PPh}_{3}\right)_{2}\left(\mathrm{PhNH}_{2}\right) & 3.3 & 6.4 & 2.1 & 5.3 & -37.9 \\ \text { cis- } \mathrm{RhI}\left(\mathrm{PPh}_{3}\right)_{2}\left(\mathrm{Et}_{2} \mathrm{NH}\right) & -5.8 & 0.5 & -10.8 & -4.6 & -34.1 \\ \text { trans- } \mathrm{RhI}\left(\mathrm{PPh}_{3}\right)_{2}\left(\mathrm{Et}_{2} \mathrm{NH}\right) & 6.3 & 10.4 & 0.0 & 4.2 & -35.4 \\ \text { cis- } \mathrm{RhI}\left(\mathrm{PPh}_{3}\right)_{2}\left(\mathrm{C}_{2} \mathrm{H}_{4}\right) & -2.3 & 2.0 & -5.4 & -1.1 & -32.6 \\ \text { trans }-\mathrm{RhI}\left(\mathrm{PPh}_{3}\right)_{2}\left(\mathrm{C}_{2} \mathrm{H}_{4}\right) & -4.5 & -2.5 & -8.6 & -6.6 & -33.6\end{array}$

${ }^{\mathrm{a}}$ Gas-phase at $\mathrm{T}=298.15 \mathrm{~K} .{ }^{\mathrm{b}} \Delta \mathrm{E}^{\mathrm{SMD}}+(\Delta \mathrm{G}-\Delta \mathrm{E})$ at $298.15 \mathrm{~K}$. ${ }^{\mathrm{c}}$ Solvation free energy calculated by the SDM model for the given compound (values for the reagents: $\left[\mathrm{RhCl}\left(\mathrm{PPh}_{3}\right)_{2}\right]_{2},-56.5$; $\left[\mathrm{RhI}\left(\mathrm{PPh}_{3}\right)_{2}\right]_{2}$, 56.1; $\left.\mathrm{PPh}_{3},-14.6 ; \mathrm{Cl}^{-},-60.3 ; \mathrm{I}^{-},-50.8 ; \mathrm{PhNH}_{2},-8.7 ; \mathrm{Et}_{2} \mathrm{NH},-1.0, \mathrm{C}_{2} \mathrm{H}_{4},-1.4\right)$.

Solvent effects have also been included in the calculations using the SDM solvation model ${ }^{42}$ in the $\mathrm{CH}_{2} \mathrm{Cl}_{2}$ medium $(\varepsilon=8.93)$ and this turns out to be important for the rationalization of certain trends. In particular, while solvation has either a negligible effect or favors the dimer splitting reaction by a few $\mathrm{kcal} / \mathrm{mol}$ when adding a neutral ligand, it strongly disfavors the addition of $\mathrm{X}^{-}$. This is attributable to the higher solvation energy of the free $\mathrm{X}^{-}$ions relative to the neutral species (see Table 5, footnote $\mathrm{c}$ ). Note that free $\mathrm{X}^{-}$is not better solvated than the $\left[\mathrm{RhX}_{2}\left(\mathrm{PPh}_{3}\right)_{2}\right]^{-}$ion, but the balance is shifted more in favor of the reactants side by the solvent, because the combination of $\left[\mathrm{RhX}\left(\mathrm{PPh}_{3}\right)_{2}\right]_{2}$ and $2 \mathrm{X}^{-}$is better solvated than $2\left[\mathrm{RhX}_{2}\left(\mathrm{PPh}_{3}\right)_{2}\right]^{-}$. As expected, solvation free energy is higher for the systems containing the smaller $\mathrm{Cl}$ atom. The experimentally observed higher stability of the $\mathrm{Et}_{2} \mathrm{NH}$ adduct relative to that of the $\mathrm{PhNH}_{2}$ adduct is also reproduced by the calculation only when the solvent effect is included. The $\Delta \mathrm{E}^{\mathrm{SMD}}$ 
and $\Delta \mathrm{G}^{\mathrm{SMD}}$ parameters are graphically summarized in Figure 10.

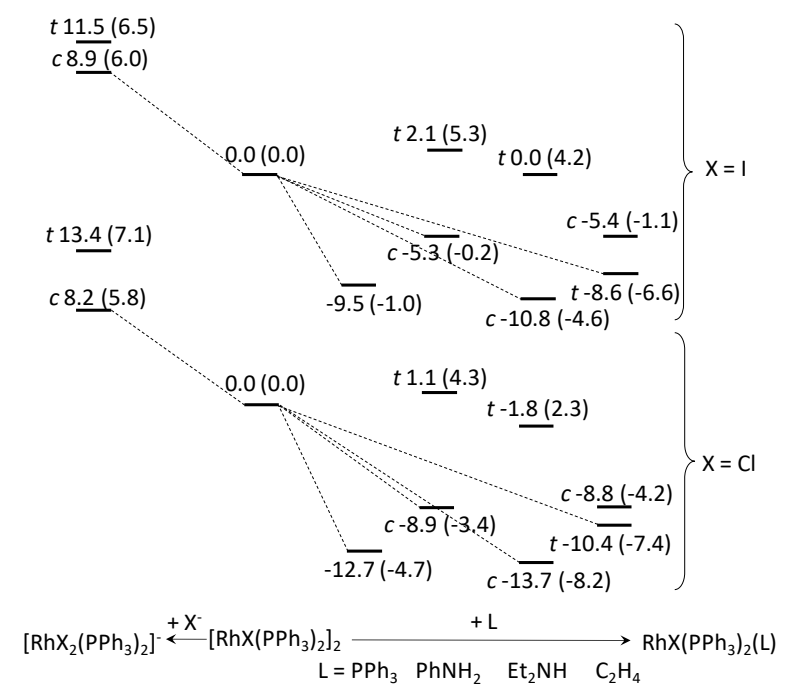

Figure 10. Relative $\Delta \mathrm{E}^{\mathrm{SMD}}$ and $\Delta \mathrm{G}^{\mathrm{SMD}}$ (in parentheses) in $\mathrm{kcal} / \mathrm{mol}$ for geometry optimized $\left[\mathrm{RhX}_{2}\left(\mathrm{PPh}_{3}\right)_{2}\right]^{-}$and $\mathrm{RhX}\left(\mathrm{PPh}_{3}\right)_{2} \mathrm{~L}\left(\mathrm{~L}=\mathrm{PPh}_{3}, \mathrm{PhNH}_{2}, \mathrm{Et}_{2} \mathrm{NH}\right.$ and $\left.\mathrm{C}_{2} \mathrm{H}_{4}\right)$, relative to $\left[\mathrm{RhX}\left(\mathrm{PPh}_{3}\right)_{2}\right]_{2}$.

Note that for all systems except the anionic ones, $\Delta \mathrm{G}^{\mathrm{SMD}}>\Delta \mathrm{E}^{\mathrm{SMD}}$ (the Gibbs parameter is more positive or less negative than the electronic energy), as expected from the reduction in molecularity (entropy decrease). The singular behavior for the anionic $\mathrm{X}^{-}$adducts can be ascribed to the increase of rotational entropy for this system, because no rotational (or vibrational) modes are associated to the monoatomic $\mathrm{X}^{-}$reagent. Roughly speaking, since the major entropic contribution to the free energy change is given by changes in the translational and rotational modes, the reactions with the bidimensional $\left(\mathrm{C}_{2} \mathrm{H}_{4}\right)$ or tridimensional $\left(\mathrm{PPh}_{3}, \mathrm{PhNH}_{2}\right)$ ligands entail the disappearance of 3 translational and 3 rotational modes whereas the reaction with zero-dimensional $\mathrm{X}^{-}$entails on one hand the disappearance of 3 translational modes and on the other hand the generation of 3 rotational modes. This effect, predicted by the gas phase calculations, will obviously be attenuated in a condensed phase and further modulated by ion pairing.

The addition of $\mathrm{L}$ to $\left[\mathrm{RhX}\left(\mathrm{PPh}_{3}\right)_{2}\right]_{2}$ results in energetic stabilization except for the addition of $\mathrm{X}^{-}$(the solvent has an important effect on this equilibrium, as already pointed out above). Indeed, we were 
unable to observe any significant conversion of $\left[\mathrm{RhX}\left(\mathrm{PPh}_{3}\right)_{2}\right]_{2}$ in the presence of excess $\mathrm{X}^{-}$. For the neutral ligands, the relative stability increases in the order $\mathrm{PhNH}_{2}<\mathrm{C}_{2} \mathrm{H}_{4}<\mathrm{PPh}_{3}<\mathrm{Et}_{2} \mathrm{NH}$ for each $\mathrm{X}$ on the $\Delta \mathrm{E}^{\mathrm{SMD}}$ scale. On the $\Delta \mathrm{G}^{\mathrm{SMD}}$ scale, on the other hand, the order is $\mathrm{PhNH}_{2}<\mathrm{PPh}_{3}<\mathrm{Et}_{2} \mathrm{NH}_{2}<\mathrm{C}_{2} \mathrm{H}_{4}$, in better agreement with the experimental evidence. Indeed, the $\mathrm{RhCl}\left(\mathrm{PPh}_{3}\right)_{2}\left(\mathrm{C}_{2} \mathrm{H}_{4}\right)$ complex is sufficiently stable to be isolated, although it readily looses the ethylene ligand unless kept under a protecting ethylene atmosphere, ${ }^{23}$ whereas we have shown above that the corresponding $\mathrm{Et}_{2} \mathrm{NH}$ adduct also exists in solution but is not sufficiently stable to be isolated.

The energy change is less negative (or more positive) when $\mathrm{X}=\mathrm{I}$ for all systems. In other words, $\left[\mathrm{RhI}\left(\mathrm{PPh}_{3}\right)_{2}\right]_{2}$ has a greater relative stability with respect to all its ligand adducts than the corresponding chloride system. This result is in agreement with all the available experimental evidence. Indeed, the more facile dissociation of $\mathrm{PPh}_{3}$ from $\mathrm{RhI}\left(\mathrm{PPh}_{3}\right)_{3}$ or $\mathrm{C}_{2} \mathrm{H}_{4}$ from $\mathrm{RhI}\left(\mathrm{PPh}_{3}\right)_{2}\left(\mathrm{C}_{2} \mathrm{H}_{4}\right)$ relative to the corresponding chloride systems has previously been discussed. ${ }^{23}$ The new experiments reported in the present contribution also illustrate the lower stability of the other ligand adducts for the iodide system (vide supra).

Another notable result of the computational study concerns the relative stability for each pair of stereoisomers: the trans geometry is preferred for the $\mathrm{C}_{2} \mathrm{H}_{4}$ adduct, whereas all other ligand adducts show a preference for the cis geometry (moderate for $\mathrm{X}^{-}$, strong for the amines). This is in perfect agreement with the experimental evidence, according to which the ethylene adduct is trans and the $\mathrm{Et}_{2} \mathrm{NH}$ adduct reported in this contribution is cis, without the detection of the trans isomer. The reason for the difference stereochemical preference may be traced to the competition between the different $\pi$ acceptors and $\pi$ donors that are present in the coordination sphere. Thus, $\mathrm{C}_{2} \mathrm{H}_{4}$ is a stronger $\pi$ acceptor and prefers to be located trans to a $\pi$ donor halide ligand, leading to a preferred trans geometry, whereas the two more weakly $\pi$ acceptor $\mathrm{PPh}_{3}$ ligands avoid competing with each other in the cis geometry for the amine and $\mathrm{X}^{-}$adducts.

Given the infrared evidence for a secondary interaction between the $\mathrm{RhX}\left(\mathrm{PPh}_{3}\right)_{2}\left(\mathrm{Et}_{2} \mathrm{NH}\right)$ complex 
and additional free $\mathrm{Et}_{2} \mathrm{NH}$, a calculation was also carried out for the $\mathrm{RhX}\left(\mathrm{PPh}_{3}\right)_{2}\left(\mathrm{Et}_{2} \mathrm{NH}\right) \cdots \mathrm{NHEt}_{2}$ adducts. Four different minima could be located, the same ones for both halide systems. Adduct (III) derives from the lower energy $\mathrm{RhX}\left(\mathrm{PPh}_{3}\right)_{2}\left(\mathrm{NHEt}_{2}\right)$ molecule $(\mathbf{I})$ and the other three (IV, $\mathbf{V}$ and VI) from a slightly higher energy minimum (II). Figure 11 shows a view of all the molecules for the $\mathrm{Cl}$ system (those of the I system are given in the Supporting Information). The relative energies and the calculated $\mathrm{NH}$ stretching frequencies are reported in Table 6. In order to take into account the $\mathrm{H}$-bond breaking in the $\mathrm{NHEt}_{2}$ reagent, the H-bonded dimer $\left(\mathrm{Et}_{2} \mathrm{NH} \ldots \mathrm{NHEt}_{2}\right)$ has been chosen as a reference point.

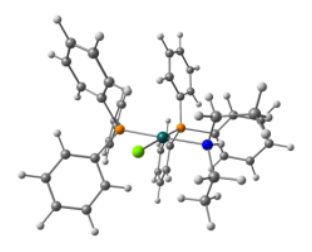

I

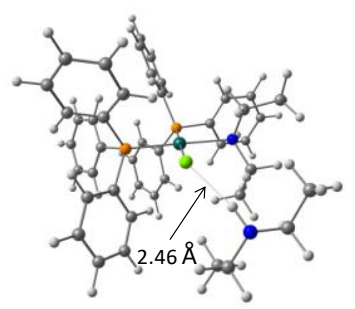

III

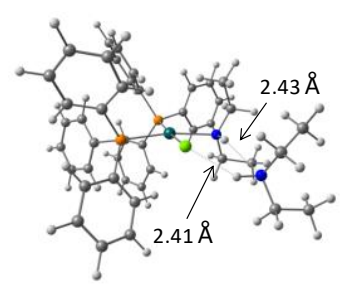

v
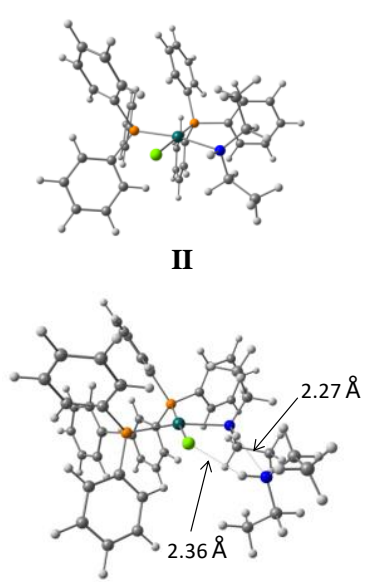

IV

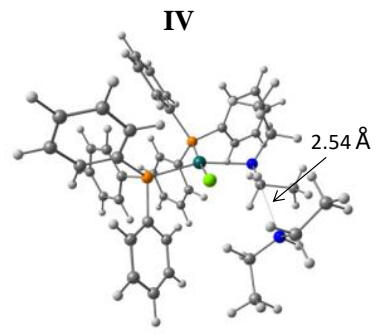

VI

Figure 11. View of the optimized geometries of $\operatorname{RhCl}\left(\mathrm{PPh}_{3}\right)_{2}\left(\mathrm{Et}_{2} \mathrm{NH}\right)$ (I and II $)$ and $\mathrm{RhCl}\left(\mathrm{PPh}_{3}\right)_{2}\left(\mathrm{Et}_{2} \mathrm{NH}\right) \cdots \mathrm{NHEt}_{2}($ III-VI).

Table 6. Energies (in $\mathrm{kcal} / \mathrm{mol}$, relative to $\mathrm{RhX}\left(\mathrm{PPh}_{3}\right)_{2}\left(\mathrm{Et}_{2} \mathrm{NH}\right)$ (I) $+1 / 2\left(\mathrm{Et}_{2} \mathrm{NH} \ldots \mathrm{NHEt}_{2}\right)$ ) and calculated $\mathrm{N}-\mathrm{H}$ stretching vibrations $\left(\right.$ in $\left.\mathrm{cm}^{-1}\right)$.

$\begin{array}{lllllll}\text { Compound } & \Delta \mathrm{E} & \Delta \mathrm{G}^{\mathrm{a}} & \Delta \mathrm{E}^{\mathrm{SMD}} & \Delta \mathrm{G}^{\mathrm{SMD}, \mathrm{b}} & v(\mathrm{NH})^{\mathrm{c}} & v(\mathrm{NH})^{\mathrm{d}}\end{array}$


(c) Chloride system

\begin{tabular}{lcccccc} 
I + 1/2 $\left(\mathrm{Et}_{2} \mathrm{NH} \ldots \mathrm{NHEt}_{2}\right)$ & 0.0 & 0.0 & 0.0 & 0.0 & 3491 & \\
$\mathbf{I I}+1 / 2\left(\mathrm{Et}_{2} \mathrm{NH} \ldots \mathrm{NHEt}_{2}\right)$ & 1.1 & 1.8 & 1.4 & 2.1 & 3392 & \\
III & -2.2 & 7.4 & -3.9 & 5.8 & 3496 & 3499 \\
IV & -3.0 & 5.6 & -2.4 & 6.3 & 3479 & 3448 \\
V & -1.1 & 8.7 & -0.5 & 9.3 & 3514 & 3434 \\
VI & -1.3 & 8.9 & -0.8 & 9.4 & 3430 & 3500 \\
\hline
\end{tabular}

(d) Iodide system

$\begin{array}{lcccccc}\text { I + } \text { NHEt }_{2} & 0.0 & 0.0 & 0.0 & 0.0 & 3503 & \\ \text { II + } \text { NHEt }_{2} & 1.4 & 1.0 & 2.4 & 2.0 & 3389 & \\ \text { III } & -1.5 & 6.9 & -3.9 & 4.5 & 3505 & 3488 \\ \text { IV } & -1.8 & 4.7 & -1.6 & 4.9 & 3473 & 3446 \\ \text { V } & 0.4 & 7.9 & 0.8 & 8.2 & 3508 & 3434 \\ \text { VI } & 0.3 & 8.1 & -0.1 & 7.7 & 3442 & 3496\end{array}$

${ }^{\mathrm{a}}$ Gas-phase at $\mathrm{T}=298.15 \mathrm{~K} .{ }^{\mathrm{b}} \Delta \mathrm{E}^{\mathrm{SMD}}+(\Delta \mathrm{G}-\Delta \mathrm{E})$ at $298.15 \mathrm{~K} .{ }^{\mathrm{c}}$ Coordinated $\mathrm{Et}_{2} \mathrm{NH}$ ligand. ${ }^{\mathrm{d}} \mathrm{H}-$ bonded $\mathrm{Et}_{2} \mathrm{NH}$ ligand.

Structures I and II differ in the orientation of the $\mathrm{Et}_{2} \mathrm{NH}$ ligand relative to the rest of the molecule; the $\mathrm{NH}$ vector points toward one of the $\mathrm{Ph}$ rings of the cis $\mathrm{PPh}_{3}$ ligand in the lower energy I and towards the $\mathrm{X}$ ligand in the slightly less stable II. Structure I can only establish an H bond as a proton acceptor via the $\mathrm{X}$ ligand with the $\mathrm{NH}$ bond of the external $\mathrm{NHEt}_{2}$ molecule, leading to III. Structures IV and V feature the same $\mathrm{X} \cdots \mathrm{H}-\mathrm{N}$ interaction but also an additional $\mathrm{N}-\mathrm{H} \cdots \mathrm{N}$ bond involving the coordinated amine as proton donor and the outer sphere amine as proton acceptor, whereas VI contains only the N$\mathrm{H} \cdots \mathrm{N}$ interaction with the coordinated amine providing the proton to the external amine. The lowest energy structure is III when the solvation effects are taken into account, whereas IV is slightly favored in the gas phase. Note, however, that the energy difference between these two structures is small. The H-bonds are shorter in IV. 
Structures I and IV also give the best agreement between the calculated $v_{\mathrm{NH}}$ frequencies and the experimental data. Interestingly, the two NH vibrations in IV (for the coordinated and for the hydrogen bonded $\mathrm{Et}_{2} \mathrm{NH}$ ) appear at similar frequencies, slightly red-shifted from that of $\mathbf{I}$. Considering the expected difference between the frequencies computed in the gas phase and those experimentally measured in solution, these results allow the assignment of the experimentally observed band at 3263 $\mathrm{cm}^{-1}$ to a combination of the two $v_{\mathrm{NH}}$ bands in IV. Finally, the data in Table 6 indicate a more favorable H-bond formation for the $\mathrm{Cl}$ system on the $\mathrm{E}$ scales (both gas phase and solution), whereas the process is more favorable for the I system on the Gibbs free energy scales. The experimental IR data are clearly demonstrating an easier formation of the $\mathrm{H}$-bonded adduct for the $\mathrm{Cl}$ system, suggesting that the gas phase entropy correction is not adequate to address this phenomenon. Hence, the present system is yet another useful example pointing out to the care that one has to take when using computed gas phase thermodynamic data (even when including the solvation effects) for the prediction of solution behavior.

A final computational study has addressed the halide exchange equilibrium (10), of interest because of the somewhat unexpected lack of iodide incorporation into $\left[\mathrm{RhCl}\left(\mathrm{PPh}_{3}\right)_{2}\right]_{2}$ by treatment with excess $n \mathrm{Bu}_{4} \mathrm{P}^{+} \mathrm{I}^{-}$. The equilibrium has been analyzed in the presence of the free ions (no cation) as well as with ion pairs modeled by $\mathrm{Me}_{4} \mathrm{~N}^{+} \mathrm{X}^{-}, \mathrm{Me}_{4} \mathrm{P}^{+} \mathrm{X}^{-}$, and $\mathrm{Na}^{+} \mathrm{X}^{-}$and the relevant results are presented in Table 7 . The results in the absence of cation are interesting since they show how much the right hand side is favored by solvation with respect to the gas phase. Introduction of the $\mathrm{Me}_{4} \mathrm{~N}^{+}$cation indicates that the cation-anion association has a similar effect to that of the solvent model, since the gas phase parameters are essentially identical to those in solution. Optimization of the ion pair geometry in the presence of the solvent model does not greatly affect the results, relative to those obtained by correcting the gas phase energy by solvation effects, and the effect of $\mathrm{Me}_{4} \mathrm{~N}^{+}$and $\mathrm{Me}_{4} \mathrm{P}^{+}$is essentially equivalent, whereas that of $\mathrm{Na}^{+}$differs significantly, stabilizing the right hand side of the equilibrium by more than $10 \mathrm{kcal} / \mathrm{mol}$. Clearly, the $\mathrm{Na}^{+}$results are not quantitatively relevant because $\mathrm{NaCl}$ and $\mathrm{NaI}$ are essentially insoluble in $\mathrm{CH}_{2} \mathrm{Cl}_{2}$. However, the stronger $\mathrm{Na}^{+} \mathrm{Cl}^{-}$association relative to $\mathrm{Na}^{+} \mathrm{I}^{-}$, which is expected from first 
principles, is well reflected by the computed energy values, and the smaller solubility of $\mathrm{NaCl}$ than $\mathrm{NaI}$ (not known for $\mathrm{CH}_{2} \mathrm{Cl}_{2}$ solution, but confirmed in most polar aprotic organic solvents such as acetone and $\mathrm{MeCN})^{62}$ will in fact further accentuate the preference of equilibrium (10) for the right hand side. Quantitative agreement with experiment is not achieved, since the equilibrium appears to be displaced to the left hand side in the presence of soluble halide sources, however the calculated values are not too far from the expected outcome, considering that the calculation of free energy differences in condensed phases, especially when ionic species are involved, is one of the most challenging areas of computational chemistry, and the trend is as expected.

$$
\left[\mathrm{RhCl}\left(\mathrm{PPh}_{3}\right)_{2}\right]_{2}+2 \mathrm{I}^{-} \rightleftarrows\left[\mathrm{RhI}\left(\mathrm{PPh}_{3}\right)_{2}\right]_{2}+2 \mathrm{Cl}^{-}
$$

Table 7. Various energetic parameters (in $\mathrm{kcal} / \mathrm{mol}$ ) for equilibrium (10), depending on the nature of the counter-cation.

\begin{tabular}{lcccc}
\hline Cation & $\Delta \mathrm{E}$ & $\Delta \mathrm{G}^{\mathrm{a}}$ & $\Delta \mathrm{E}^{\mathrm{SMD}}$ & $\Delta \mathrm{G}^{\mathrm{SMD}}$ \\
\hline- & 14.4 & 14.4 & -4.1 & $-4.1^{\mathrm{b}}$ \\
$\mathrm{Me}_{4} \mathrm{~N}^{+\mathrm{c}}$ & -6.8 & -5.8 & -5.9 & $-4.8^{\mathrm{b}}$ \\
$\mathrm{Me}_{4} \mathrm{~N}^{+\mathrm{d}}$ & & & -5.2 & -2.0 \\
$\mathrm{Me}_{4} \mathrm{P}^{+\mathrm{d}}$ & & -4.9 & -1.2 \\
$\mathrm{Na}^{+\mathrm{d}}$ & -15.6 & -14.9 \\
${ }^{\mathrm{a}}$ Gas-phase at $\mathrm{T}=298.15 \mathrm{~K} .{ }^{\mathrm{b}} \Delta \mathrm{E}^{\mathrm{SMD}}+(\Delta \mathrm{G}-\Delta \mathrm{E})$ at $298.15 \mathrm{~K} .{ }^{c}$ Optimized in the gas phase and SMD \\
calculation at the frozen geometry. ${ }^{\mathrm{d}}$ Optimization with SMD.
\end{tabular}

\section{Conclusion}

The present investigation has provided strong evidence that the recently reported ${ }^{12} \mathrm{RhCl}_{3} \cdot 3 \mathrm{H}_{2} \mathrm{O} / \mathrm{I}^{-}$ catalyst for the hydroamination of ethylene by aniline is activated by reduction to a $\mathrm{Rh}^{\mathrm{I}}$ active species. 
This catalyst is more robust than the $\mathrm{PtBr}_{2} / \mathrm{Br}^{-}$system, no significant loss of activity after 4 days at $150^{\circ} \mathrm{C}$ being observed in a recycle experiment, whereas the Pt-based catalyst is totally deactivated by the catalytic medium. ${ }^{6,11}$ The catalytic activity of the Rh-based catalyst, however, is much lower than that of the Pt-based catalyst, as shown by the reaction kinetic profile. The solution studies of the $\left[\mathrm{RhI}\left(\mathrm{PPh}_{3}\right)_{2}\right]_{2}$ system and of the chlorido analogue at room temperature show ligand addition equilibria to yield mononuclear $\mathrm{RhX}\left(\mathrm{PPh}_{3}\right)_{2}(\mathrm{~L})$ species $\left(\mathrm{L}=\mathrm{C}_{2} \mathrm{H}_{4}, \mathrm{PPh}_{3}, \mathrm{PhNH}_{2}, \mathrm{X}^{-}\right.$and the model $\mathrm{Et}_{2} \mathrm{NH}$ amine $)$ that are of comparable stability (marginally more stable according to DFT calculations, for $\mathrm{C}_{2} \mathrm{H}_{4}, \mathrm{PPh}_{3}$ and $\mathrm{Et}_{2} \mathrm{NH}$; or less stable, for $\mathrm{PhNH}_{2}$ and $\mathrm{X}^{-}$). The reaction of $\mathrm{RhCl}_{3} \cdot 3 \mathrm{H}_{2} \mathrm{O}$ in the presence of $\mathrm{PPh}_{3}, \mathrm{I}^{-}$ and $\mathrm{PhNH}_{2}$ leads to $\left[\mathrm{RhCl}\left(\mathrm{PPh}_{3}\right)_{2}\right]_{2}$ as the major species, without notable halide exchange, thus suggesting that iodide is not needed at the level of the catalyst resting state. The effect of high temperature and pressure conditions on the equilibria cannot be easily predicted, but it may be speculated that either $\mathrm{RhCl}\left(\mathrm{PPh}_{3}\right)_{2}\left(\mathrm{C}_{2} \mathrm{H}_{4}\right)$ or $\left[\mathrm{RhCl}\left(\mathrm{PPh}_{3}\right)_{2}\right]_{2}$ are the rate-determining intermediates (resting state) of the catalytic cycle. An ionic $\left[\mathrm{RhClI}\left(\mathrm{PPh}_{3}\right)_{2}\right]^{-}$or $\left[\mathrm{RhI}_{2}\left(\mathrm{PPh}_{3}\right)_{2}\right]^{-}$complex certainly does not appear to play a significant role, thus the promoting effect of iodide on the catalytic activity must be rationalized through its effect on the rate-determining transition state, which is still currently unknown. Future work will address the catalytic mechanism through computations.

Acknowledgement. We are grateful to the ANR (Agence Nationale de la Recherche, Grant No. NT09_442499), the IUF (Institut Universitaire de France), the CNRS and the RFBR (Russian Foundation for Basic Research; France-Russia bilateral grant No. 08-03-92506) for financial support, as well as the CINES (Centre Informatique National de l'Enseignement Supérieur) and the CICT (Centre Interuniversitaire de Calcul de Toulouse, project CALMIP) for granting free computational time.

Supporting Information Available. NMR spectrum of $\left[\mathrm{RhCl}\left(\mathrm{PPh}_{3}\right)_{2}\right]_{2}$; Cartesian coordinates of all 
optimized geometries (25 pages). Crystallographic data (excluding structure factors) have been deposited with the Cambridge Crystallographic Data Centre as supplementary publication no. CCDC 833545. Copies of the data can be obtained free of charge on application to the Director, CCDC, 12 Union Road, Cambridge CB2 1EZ, UK (fax: (+44) 1223-336-033; e-mail: deposit@ccdc.cam.ac.uk).

\section{References}

1. Brunet, J. J.; Cadena, M.; Chu, N. C.; Diallo, O.; Jacob, K.; Mothes, E., Organometallics 2004, 23, 1264-1268.

2. Brunet, J. J.; Chu, N. C.; Diallo, O., Organometallics 2005, 24, 3104-3110.

3. Brunet, J.-J.; Chu, N.-C.; Rodriguez-Zubiri, M., Eur. J. Inorg. Chem. 2007, 4711-4722.

4. Rodriguez-Zubiri, M.; Anguille, S.; Brunet, J.-J., J. Mol. Catal. A 2007, 271, 145-150.

5. Dub, P. A.; Rodriguez-Zubiri, M.; Daran, J.-C.; Brunet, J.-J.; Poli, R., Organometallics 2009, 28, 4764-4777.

6. Dub, P. A.; Rodriguez-Zubiri, M.; Baudequin, C.; Poli, R., Green Chem. 2010, 1392-1396.

7. Dub, P. A.; Filippov, O. A.; Belkova, N. V.; Rodriguez-Zubiri, M.; Poli, R., J. Phys. Chem. A 2009, 113, 6348-6355.

8. Dub, P. A.; Daran, J.-C.; Levina, V. A.; Belkova, N. V.; Shubina, E. S.; Poli, R., J. Organomet. Chem 2011, 696, 1174-1183.

9. Dub, P. A.; Poli, R., J. Mol. Catal. A 2010, 324, 89-96.

10. Dub, P. A.; Poli, R., J. Am. Chem. Soc. 2010, 132, 13799-13812.

11. Dub, P. A.; Béthegnies, A.; Poli, R., Organometallics submitted.

12. Baudequin, C.; Brunet, J.-J.; Rodriguez-Zubiri, M., Organometallics 2007, 26, 5264-5266.

13. Coulson, D. R., Tetrahedron Lett. 1971, 429-430.

14. Coulson, D. R., US 3,758,586 1973.

15. Diamond, S. E.; Mares, F.; Szalkiewicz, A., Fundam. Res. Homogeneous Catal. 1979, 3, 345-358.

16. Diamond, S. E.; Szalkiewicz, A.; Mares, F., J. Am. Chem. Soc. 1979, 101, 490-491.

17. Diamond, S. E.; Mares, F., US 4,215,218 1980.

18. Steinborn, D.; Taube, R., Zeitschrift Fur Chemie 1986, 26, 349-359.

19. Krukowka, E.; Taube, R.; Steinborn, D., DD 296,909 1991.

20. Hahn, C.; Spiegler, M.; Herdtweck, E.; Taube, R., Eur. J. Inorg. Chem. 1999, 435-440.

21. Dorta, R.; Egli, P.; Zurcher, F.; Togni, A., J. Am. Chem. Soc. 1997, 119, 10857-10858.

22. Maitlis, P. M.; Haynes, A.; James, B. R.; Catellani, M.; Chiusoli, G. P., Dalton Trans. 2004, 34093419.

23. Osborn, J. A.; Jardine, F. H.; Young, J. F.; Wilkinson, G., J. Chem. Soc. A 1966, 1711-1732.

24. Hartley, F. R.; Murray, S. G.; Potter, D. M., J. Organomet. Chem. 1983, 254, 119-26.

25. Colebrooke, S. A.; Duckett, S. B.; Lohman, J. A. B.; Eisenberg, R., Chem. Eur. J. 2004, 10, 24592474.

26. Hughes, R. P., Rhodium. In Comprehensive Organometallic Chemistry, Wilkinson, G.; Stone, F. G. A.; Abel, E. W., Eds. Pergamon: Oxford, 1982; Vol. 5, pp 277-540.

27. Sharp, P. R., Rhodium. In Comprehensive Organometallic Chemistry II, Abel, E. W.; Stone, F. G.; Wilkinson, G., Eds. Pergamon: Oxford, 1995; Vol. 8, pp 115-302.

28. Altomare, A.; Burla, M.; Camalli, M.; Cascarano, G.; Giacovazzo, C.; Guagliardi, A.; Moliterni, A.; Polidori, G.; Spagna, R., J. Appl. Cryst. 1999, 32, 115-119. 
29. Sheldrick, G. M., Acta Cryst. A 2008, 64, 112-122.

30. Spek, A. L., J. Appl. Cryst. 2003, 36, 7-13.

31. Burnett, M. N.; Johnson, C. K., ORTEPIII, Report ORNL-6895. . Oak Ridge National Laboratory: Oak Ridge, Tennessee, U.S. , 1996.

32. Farrugia, L. J., J. Appl. Crystallogr. 1997, 32, 565.

33. Frisch, M. J.; Trucks, G. W.; Schlegel, H. B.; Scuseria, G. E.; Robb, M. A.; Cheeseman, J. R.; Scalmani, G.; Barone, V.; Mennucci, B.; Petersson, G. A.; Nakatsuji, H.; Caricato, M.; Li, X.; Hratchian, H. P.; Izmaylov, A. F.; Bloino, J.; Zheng, G.; Sonnenberg, J. L.; Hada, M.; Ehara, M.; Toyota, K.; Fukuda, R.; Hasegawa, J.; Ishida, M.; Nakajima, T.; Honda, Y.; Kitao, O.; Nakai, H.; Vreven, T.; Montgomery, J., J. A.; Peralta, J. E.; Ogliaro, F.; Bearpark, M.; Heyd, J. J.; Brothers, E.; Kudin, K. N.; Staroverov, V. N.; Kobayashi, R.; Normand, J.; Raghavachari, K.; Rendell, A.; Burant, J. C.; Iyengar, S. S.; Tomasi, J.; Cossi, M.; Rega, N.; Millam, N. J.; Klene, M.; Knox, J. E.; Cross, J. B.; Bakken, V.; Adamo, C.; Jaramillo, J.; Gomperts, R.; Stratmann, R. E.; Yazyev, O.; Austin, A. J.; Cammi, R.; Pomelli, C.; Ochterski, J. W.; Martin, R. L.; Morokuma, K.; Zakrzewski, V. G.; Voth, G. A.; Salvador, P.; Dannenberg, J. J.; Dapprich, S.; Daniels, A. D.; Farkas, Ö.; Foresman, J. B.; Ortiz, J. V.; Cioslowski, J.; Fox, D. J., Gaussian 09, Revision A.1. Gaussian, Inc.: Wallingford CT, 2009.

34. Zhao, Y.; Truhlar, D. G., Theor. Chem. Acc. 2008, 120, 215-241.

35. Andrae, D.; Haussermann, U.; Dolg, M.; Stoll, H.; Preuss, H., Theor. Chim. Acta 1990, 77, $123-$ 141.

36. Haussermann, U.; Dolg, M.; Stoll, H.; Preuss, H.; Schwerdtfeger, P.; Pitzer, R. M., Mol. Phys. 1993, 78, 1211-1224.

37. Kuchle, W.; Dolg, M.; Stoll, H.; Preuss, H., J. Chem. Phys. 1994, 100, 7535-7542.

38. Leininger, T.; Nicklass, A.; Stoll, H.; Dolg, M.; Schwerdtfeger, P., J. Chem. Phys. 1996, 105, 10521059.

39. Ehlers, A. W.; Bohme, M.; Dapprich, S.; Gobbi, A.; Hollwarth, A.; Jonas, V.; Kohler, K. F.; Stegmann, R.; Veldkamp, A.; Frenking, G., Chem. Phys. Lett. 1993, 208, 111-114.

40. Check, C. E.; Faust, T. O.; Bailey, J. M.; Wright, B. J.; Gilbert, T. M.; Sunderlin, L. S., J. Phys. Chem. A 2001, 105, 8111-8116.

41. Glukhovtsev, M. N.; Pross, A.; McGrath, M. P.; Radom, L., J. Chem. Phys. 1995, 103, 1878-1885.

42. Marenich, A. V.; Cramer, C. J.; Truhlar, D. G., J. Phys. Chem. B 2009, 113, 6378-6396.

43. Braga, A. A. C.; Ujaque, G.; Maseras, F., Organometallics 2006, 25, 3647-3658.

44. Dowerah, D.; Radonovich, L. J.; Woolsey, N. F.; Heeg, M. J., Organometallics 1990, 9, 614-620.

45. Petrucci, M. G. L.; Kakkar, A. K., Organometallics 1998, 17, 1798-1811.

46. Ball, G. E.; Cullen, W. R.; Fryzuk, M. D.; Henderson, W. J.; James, B. R.; MacFarlane, K. S., Inorg. Chem. 1994, 33, 1464-8.

47. Curtis, M. D.; Butler, W. M.; Greene, J., Inorg. Chem. 1978, 17, 2928-2931.

48. Vallarino, L. M., Inorg. Chem. 1965, 4, 161-165.

49. Brunner, H.; Zettler, C.; Zabel, M., Z. Anorg. Allg. Chem. 2003, 629, 1131-1135.

50. Bennett, M. J.; Donaldson, P. B., Inorg. Chem. 1977, 16, 655-660.

51. Poli, R.; Owens, B. E.; Linck, R. G., Inorg. Chem. 1992, 31, 662-667.

52. Mata, J. A.; Maria, S.; Daran, J.-C.; Poli, R., Eur. J. Inorg. Chem. 2006, 2624-2633.

53. Linck, R. G.; Owens, B. E.; Poli, R.; Rheingold, A. L., Gazz. Chim. Ital. 1991, 121, 163-168.

54. Aullon, G.; Ujaque, G.; Lledos, A.; Alvarez, S.; Alemany, P., Inorg. Chem. 1998, 37, 804-813.

55. Binger, P.; Haas, J.; Glaser, G.; Goddard, R.; Kruger, C., Chem. Ber. 1994, 127, 1927-1929.

56. Wang, K.; Goldman, M. E.; Emge, T. J.; Goldman, A. S., J. Organomet. Chem. 1996, 518, 55-68.

57. Boettcher, H.-C.; Mayer, P., Z. Naturforsch. B 2008, 63, 1035-1039.

58. Schnabel, R. C.; Roddick, D. M., Inorg. Chem. 1993, 32, 1513-1518.

59. Oster, S. S.; Jones, W. D., Polyhedron 2004, 23, 2959-2965.

60. Grushin, V. V.; Marshall, W. J., J. Am. Chem. Soc. 2004, 126, 3068-3069.

61. Marshall, W. J.; Aullon, G.; Alvarez, S.; Dobbs, K. D.; Grushin, V. V., Eur. J. Inorg. Chem. 2006, 
3340-3345.

62. Burgess, J., Metal Ions in Solution. Ellis Horwood: New York, 1978. 


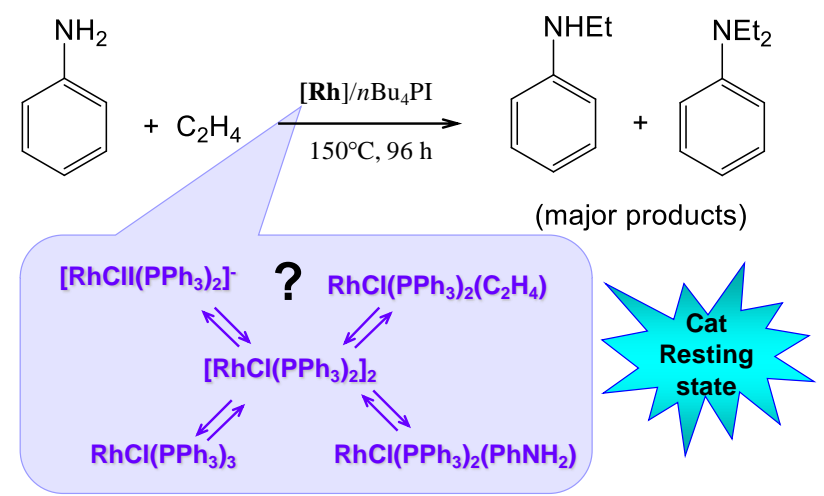

The solution behavior of $\left[\mathrm{RhX}\left(\mathrm{PPh}_{3}\right)_{2}\right]_{2}(\mathrm{X}=\mathrm{Cl}, \mathrm{I})$ in the presence of $\mathrm{PPh}_{3}, \mathrm{C}_{2} \mathrm{H}_{4}, \mathrm{PhNH}_{2}, \mathrm{Et}_{2} \mathrm{NH}$ and the corresponding $\mathrm{X}^{-}$yields information on the probable catalyst resting state during the $\mathrm{RhCl}_{3} \cdot 3 \mathrm{H}_{2} \mathrm{O} / \mathrm{PPh}_{3} / n \mathrm{Bu}_{4} \mathrm{PI}$ catalyzed hydroamination of ethylene by aniline. The transformation of the precatalyst into an active $\mathrm{Rh}^{\mathrm{I}}$ species is supported by the observed reduction of the $\mathrm{RhCl}_{3} \cdot 3 \mathrm{H}_{2} \mathrm{O} / \mathrm{PPh}_{3} / n \mathrm{Bu} 4 \mathrm{PI} / \mathrm{PhNH}_{2}$ mixture under catalytic conditions to yield mostly $\left[\mathrm{RhCl}\left(\mathrm{PPh}_{3}\right)_{2}\right]_{2}$ and by the catalytic activity when using $\left[\mathrm{RhI}\left(\mathrm{PPh}_{3}\right)_{2}\right]_{2}$ in place of $\mathrm{RhCl}_{3} \cdot 3 \mathrm{H}_{2} \mathrm{O}$. 